\title{
Seasonal and spatial changes in the zooplankton community of Kongsfjorden, Svalbard
}

\author{
Wojciech Walkusz, ${ }^{1}$ Slawek Kwasniewski, ${ }^{1}$ Stig Falk-Petersen, ${ }^{2}$ Haakon Hop, ${ }^{2}$ Vigdis Tverberg, ${ }^{2}$ \\ Piotr Wieczorek ${ }^{1}$ \& Jan Marcin Weslawski ${ }^{1}$ \\ 1 Institute of Oceanology, Polish Academy of Sciences, Powstancow Warszawy St. 55, PL-81-712 Sopot, Poland \\ 2 Norwegian Polar Institute, Polar Environmental Centre, NO-9296 Tromsø, Norway
}

\section{Keywords}

Advection; Calanus; fjords; Kongsfjorden;

Svalbard; zooplankton.

\section{Correspondence}

Wojciech Walkusz, Institute of Oceanology

PAS, Powstancow Warszawy St. 55,

PL-81-712 Sopot, Poland. E-mail:

walwo@iopan.gda.pl

doi:10.1111/j.1751-8369.2009.00107.x

\begin{abstract}
Seasonal changes in the zooplankton composition of the glacially influenced Kongsfjorden, Svalbard $\left(79^{\circ} \mathrm{N}, 12^{\circ} \mathrm{E}\right)$, and its adjacent shelf were studied in 2002. Samples were collected in the spring, summer and autumn in stratified hauls (according to hydrographic characteristics), by means of a $0.180-\mathrm{mm}$ Multi Plankton Sampler. A strong front between the open sea and the fjord waters was observed during the spring, preventing water mass exchange, but was not observed later in the season. The considerable seasonal changes in zooplankton abundance were related to the seasonal variation in hydrographical regime. The total zooplankton abundance during the spring (40-2010 individuals $\mathrm{m}^{-3}$ ) was much lower than in the summer and autumn (41010560 individuals $\mathrm{m}^{-3}$ ). The main factors shaping the zooplankton community in the fjord include: the presence of a local front, advection, the flow pattern and the decreasing depth of the basin in the inner fjord. Presumably these factors regulate the gross pattern of zooplankton density and distribution, and override the importance of biological processes. This study increased our understanding of seasonal processes in fjords, particularly with regard to the strong seasonal variability in the Arctic.
\end{abstract}

Arctic marine ecosystems have recently received increased attention because they are considered to be sensitive to climate change (Fleming et al. 1997; Wlodarska-Kowalczuk \& Weslawski 2001; Willis et al. 2006). Their most characteristic feature is the strong seasonality that influences aspects varying from taxonomic composition to functional dynamics (Weslawski et al. 1988; Falk-Petersen et al. 1990; Falk-Petersen et al. 2000).

Relatively little information is available on the seasonal aspects of zooplankton ecology from Arctic and subArctic waters (Minoda 1967; Oshurkov et al. 1982; Hassel 1986; Richter 1995; Arashkievich et al. 2002; Astthorsson \& Gislason 2003). In this respect, even less is known from fjords in the Spitsbergen region (Weslawski et al. 1988; Lischka \& Hagen 2005).

The following paradigms are widely accepted in the literature on the basis of up-to-date studies: (a) there is a single, short and pronounced phytoplankton bloom; (b) the zooplankton density and biomass peak at least one month after the phytoplankton bloom; (c) there is a large increase in the pelagic biomass from winter to summer conditions; (d) the bloom starts at the ice edge, and spreads to the water column as the ice retreats (Melnikov 2000; Cooney et al. 2001; Astthorsson \& Gislason 2003).

The semi-enclosed fjordic basins of Svalbard are of interest today, as the ongoing warming of the European Arctic has already resulted in a reduction of ice cover, and major changes in marine ecosystems are expected (e.g., Willis et al. 2007; Stempniewicz et al. 2007). Because the fjordic hydrography differs from the shelf waters and open Arctic basin, we were interested in whether or not the paradigm of Arctic zooplankton seasonality is the same in fjords as in open water. The fjords of Spitsbergen may be suitable for observing modifications of the ecosystem structure and functioning as a result of climate change, mediated, in this case, by the variable influence of the Arctic and Atlantic water masses (Cottier et al. 2005).

This study was carried out in Kongsfjorden, a glacial fjord on the western coast of Spitsbergen, in the Svalbard Archipelago. The fjord is strongly influenced by both the 
inflow of warm Atlantic water (AW) from the West Spitsbergen Current (WSC) and freshwater run-off from the surrounding tidal glaciers. Although our basic knowledge of the Kongsfjorden ecosystem has recently improved (e.g., Hop et al. 2002; Svendsen et al. 2002; Hop et al. 2006), the ecosystem dynamics of the fjord is still poorly understood. Mainly for logistic reasons, the fjord has mostly been studied during summer, when it is accessible by research vessels. The summer productive period is of great importance for Arctic ecosystems. Crucial processes (e.g., reproduction) take place during other seasons. However, sufficient information on these processes is still lacking.

The aim of this study was to fill the gap in our knowledge of seasonal changes in zooplankton composition and abundance in Kongsfjorden. The survey included stations inside as well as outside the fjord in order to reveal possible interactions between the fjord and the open sea. The biological dynamics of the zooplankton community were studied in relation to hydrography, although other factors are also considered in the discussion of the results.

\section{Methods}

Zooplankton was collected during the spring (11-17 April), summer (29-30 July) and autumn (21-23 September) of 2002, along a transect from the shelf slope (Fram Strait region) to Kongsfjorden on Spitsbergen, Svalbard, from the RV Lance, RV Oceania and RV Jan Mayen, respectively. All of the samples were collected during the daytime to avoid the potential influence of vertical migrations. The horizontal extent of sampling stations encompassed the main features of the topography of the bottom of the fjord and the adjacent shelf. Two stations (V6 and V10) were established outside of the fjord (at the slope and at the entrance to the shelf trench), whereas five stations (K0, K1, K2, K3 and K5) were located within Kongsfjorden (Fig. 1). The sampling gear used at most of the stations was a Multi Plankton Sampler (Hydro-Bios, Kiel-Holtenau, Germany), with a $0.25-\mathrm{m}^{2}$ net opening equipped with five nets of $0.180-\mathrm{mm}$ mesh size. Only at station $\mathrm{K} 5$ in the spring was zooplankton collected from the ice with a WP-2 net (mouth area $0.25 \mathrm{~m}^{2}$, mesh size $0.180 \mathrm{~mm}$ ). Except for the WP-2 sampling, the zooplankton sampling was vertically stratified (Table 1), reflecting the hydrological structure of the water column revealed by temperature and salinity measurements taken prior to the plankton net sampling. In most cases, samples were collected in the entire water column, from the bottom to the surface. In the summer at the station V6 (bottom depth $1100 \mathrm{~m}$ ), zooplankton was collected down to only $400 \mathrm{~m}$ because of unfavourable weather conditions. In the spring and summer, one haul (i.e., one replicate) was taken from each station, whereas in the autumn two replicates were taken, and the values presented here are the mean of the individual hauls. The stratified distribution of important taxa and their seasonal variability are presented against the background of the hydrographic conditions. For practical purposes, the vertical distribution for Calanus species at station V6 is limited to the upper $400 \mathrm{~m}$ : below this depth their abundance was extremely low.

Samples were preserved in $4 \%$ solution of buffered formaldehyde in seawater. The sorting and identification of zooplankton were carried out at the Institute of Oceanology, Polish Academy of Sciences, Sopot, Poland. Most of the Copepoda were identified to species or genus level, whereas the remaining taxa were identified to the lowest possible taxonomical level. For larger copepods that were collected representatively (e.g., Calanus finmarchicus, Calanus glacialis, Calanus hyperboreus, Metridia longa and Pseudocalanus spp.), the copepodid developmental stages were also identified. In order to distinguish the three Calanus species, the identification criteria presented by
Fig. 1 The fjord Kongsfjorden, on the west coast of Spitsbergen, Svalbard, showing the locations of the sampling stations. Patchy areas indicate tidal glaciers.

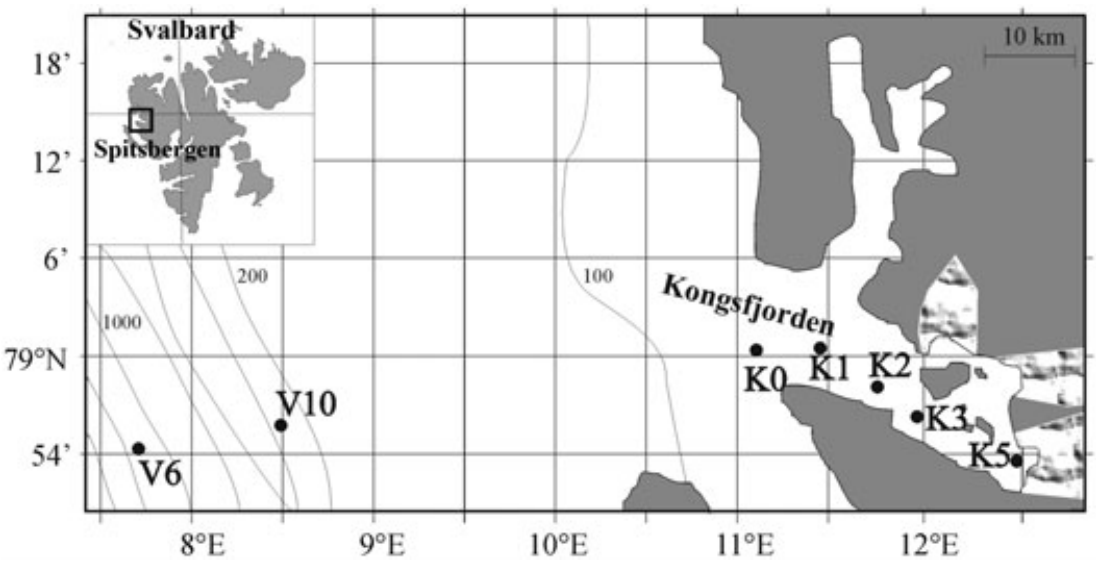

255 
Table 1 Extent of sampling strata $(\mathrm{m})$ at each season and station in Kongsfjorden. Samples were obtained by means of a Multi Plankton Sampler, except for at station K5 in spring (WP-2 net).

\begin{tabular}{lll}
\hline Station & Depth strata $(\mathrm{m})$ & Date, 2002 \\
\hline V6 & Spring & \\
V10 & $1100-900-600-120-0$ & 17 April \\
K0 & $275-200-75-0$ & 17 April \\
K1 & $320-180-100-25-0$ & 17 April \\
K2 & $335-200-75-25-0$ & 16 April \\
K3 & $200-150-100-50-0$ & 16 April \\
K5 & $330-250-100-50-0$ & 15 April \\
& $76-0$ & 11 April \\
V6 & Summer & \\
V10 & $500-360-200-100-40-0$ & 29 July \\
K0 & $320-250-130-50-20-0$ & 29 July \\
K1 & $320-220-160-80-20-0$ & 29 July \\
K2 & $350-210-160-100-40-0$ & 30 July \\
K3 & $320-260-160-80-20-0$ & 30 July \\
K5 & $320-230-160-80-30-0$ & 30 July \\
& $88-60-40-20-0$ & 30 July \\
V6 & Autumn & \\
V10 & $1100-900-600-120-60-0$ & 21 September \\
K0 & $275-200-150-40-15-0$ & 21 September \\
K1 & $320-250-175-80-25-0$ & 21 September \\
K2 & $347-285-200-100-25-0$ & 23 September \\
K3 & $318-250-150-80-30-0$ & 23 September \\
K5 & $338-250-90-20-0$ & 23 September \\
\hline & $90-72-55-30-0$ & 23 September \\
\end{tabular}

Kwasniewski et al. (2003) were applied. The filtered water volume was estimated from flow meter readings mounted on the nets, and the zooplankton abundance presented throughout the paper is expressed as the number of individuals per $\mathrm{m}^{3}$ (ind. $\mathrm{m}^{-3}$ ).

Conductivity-temperature-density (CTD) measurements were taken along a transect running from the open sea to the fjord, in each season, and the high-resolution CTD data were used to create water mass plots. The detailed oceanographic data and a description of the water masses can be found in Cottier et al. (2005).

Hierarchical agglomerative clustering (CLUSTER) and non-metric multidimensional scaling (MDS) were applied to reveal the zooplankton similarity, with regard to zooplankton composition and abundance, between the stations (Field et al. 1982; Clarke \& Warwick 1994). Afterwards, SIMPER (similarity percentages) was used to determine the contribution of each species to the average Bray-Curtis similarity within the defined groupings. PRIMER V5.0 (Plymouth Marine Laboratory, Plymouth, UK) was used for all calculations.

In order to separate the effects related to different environmental parameters (salinity; temperature; depth interval of sampling, averaged for each layer; bottom depth), direct ordination was applied. All zooplankton abundance data were $\log _{10}$-transformed in order to reduce the influence of common taxa. Linear ordination (redundancy analysis, CANOCO for Windows 4.5; ter Braak \& Smilauer 2002) was applied based on the length of the main gradient. Significance tests were performed using Monte-Carlo restricted permutations adjusted for temporal autocorrelation.

\section{Results}

\section{Oceanography}

During the spring, a strong hydrographic front was present between the open sea (AW) and the fjord waters (Fig. 2). However, small pockets of transformed Atlantic water (TAW) were observed within the fjord area, suggesting the possibility of restricted water exchange. In the summer, the front diffused, and the advection of AW onto the shelf and into the fjord was most likely unconstrained. Meltwater spread over the surface layers from near the glacier area towards the shelf. The thickness and extent of this water mass became much more pronounced during the autumn, indicating stronger glacial discharge during this season.

\section{Zooplankton}

Hierarchical agglomerative clustering and non-metric multidimensional scaling analysis of zooplankton revealed distinctive groupings: (a) spring zooplankton; (b) zooplankton collected in shelf/open sea in summer and autumn; (c) zooplankton of the inner fjord basin collected in summer and autumn; (d) zooplankton collected in the main fjord basin in summer; and (e) zooplankton of the main basin sampled in the autumn (Fig. 3). SIMPER analysis showed a high degree of zooplankton dissimilarity between samples collected in spring and those from the remaining seasons, with the lowest dissimilarity between summer and autumn fjord zooplankton (Table 2). The contribution of species to the groupings obtained with CLUSTER and MDS analyses is shown in Table 3. In all groupings, the SIMPER analysis showed that Oithona similis was the dominant species. Besides $O$. similis, both on the shelf and in open water in summer and autumn, as well as within the grouping in spring, C. finmarchicus and Pseudocalanus spp. contributed greatly to the observed similarity. In the summer, Echinodermata larvae were the distinguishing factor for the fjord grouping, whereas in the inner basin grouping (in summer and autumn) Pseudocalanus spp. and Bivalvia larvae were the most important taxa.

Most of the taxa identified during the present study (Table 4) had been recorded previously in Svalbard 

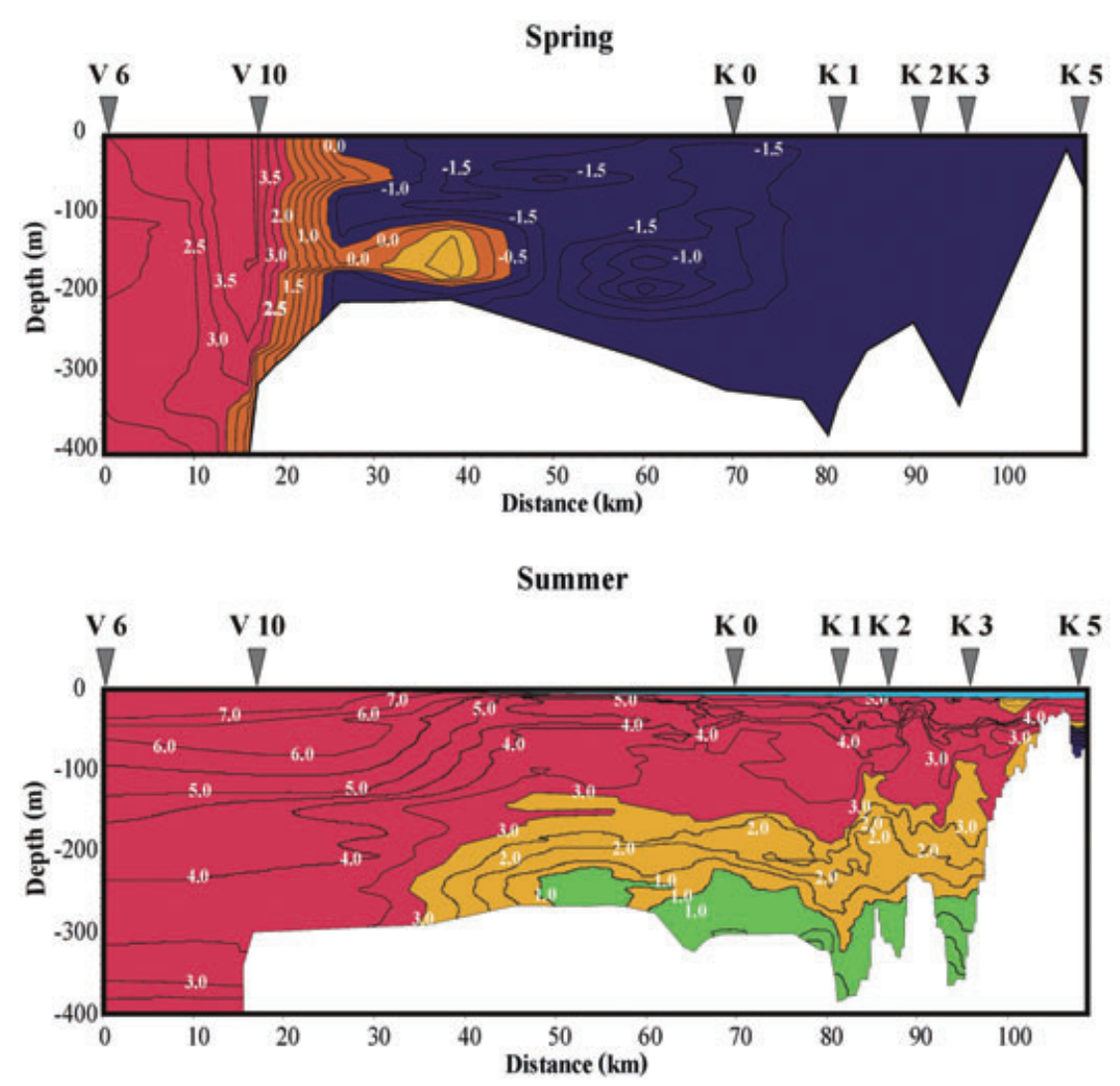

Fig. 2 Hydrographical conditions along the

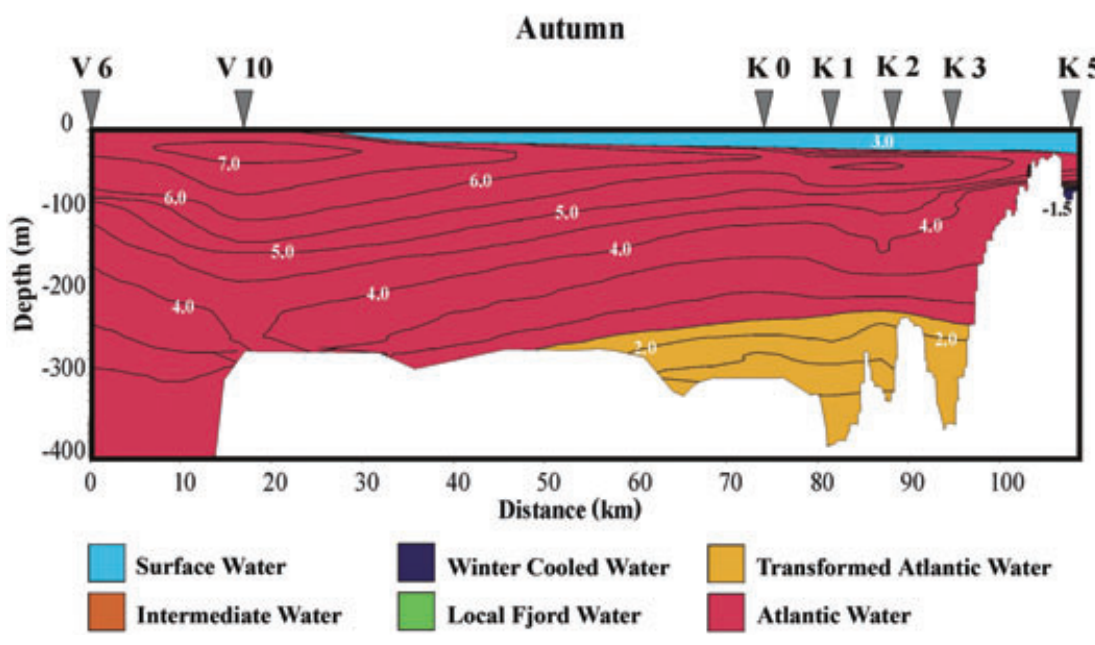
Kongsfjorden for three seasons; the positions of the sampling stations are indicated above the plots.

waters (Kwasniewski 1990; Hop et al. 2002; Walkusz et al. 2004; Hop et al. 2006). Some, however, were recorded in this area for the first time. The new zooplankton taxa included: Stephos lamellatus, Aetideopsis rostrata, Aetideus armatus, Anomalocera patersoni, Spinocalanus abyssalis and Paracalanus parvus.

The zooplankton composition and abundance were found to change with hydrographic conditions from spring to autumn. The total zooplankton abundance (ind. $\mathrm{m}^{-3}$ ) in the spring was much lower than in the summer and autumn. Also, the spatial distribution of zooplankton showed a pronounced difference in patterns for the three seasons (Fig. 4).

In spring, the highest total zooplankton density was observed in the central part of the fjord, particularly at station $\mathrm{Kl}$, reaching 2010 ind. $\mathrm{m}^{-3}$. This was mainly a result of the extremely high abundance of Cirripedia (barnacle) nauplii. The abundance of the remaining taxa was 


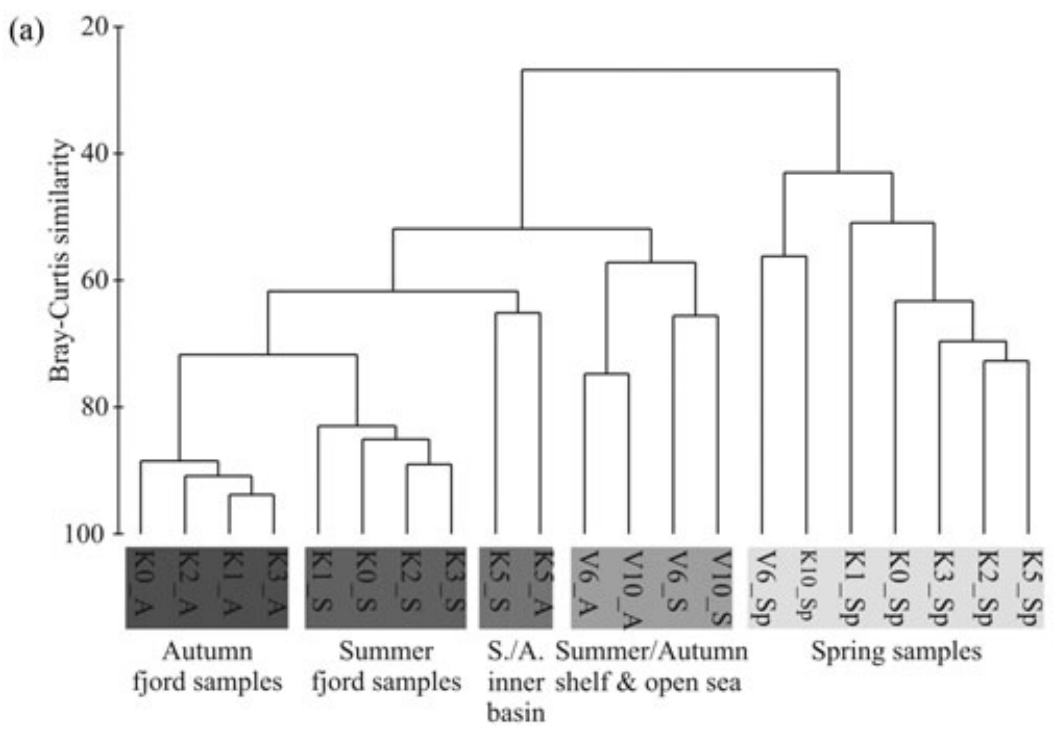

(b)

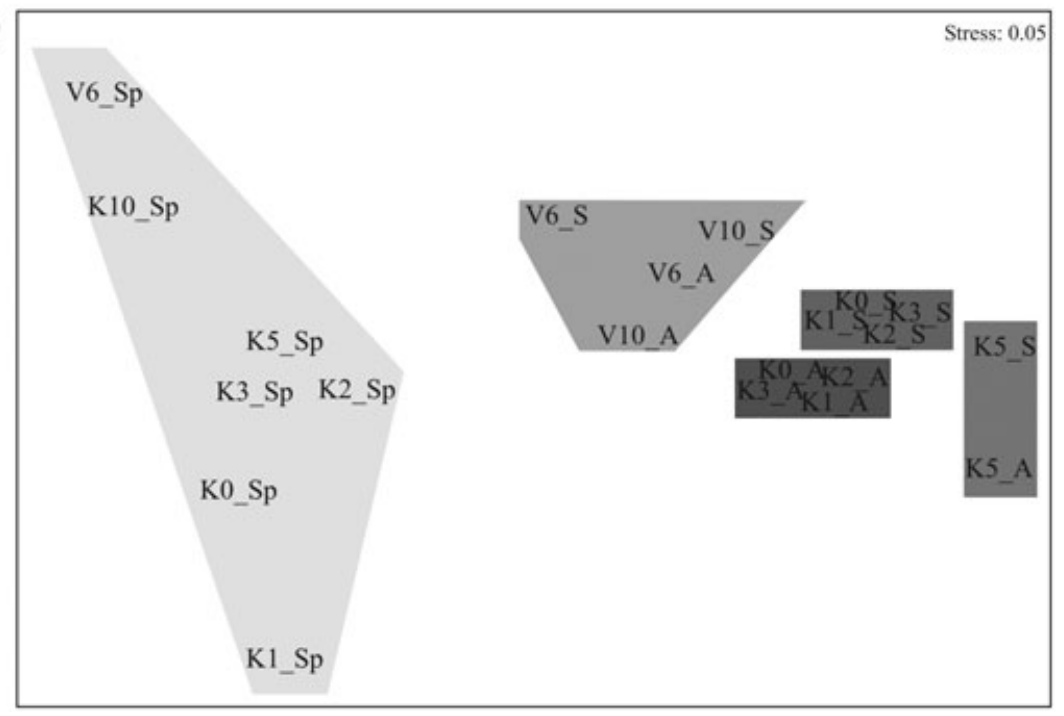

Fig. 3 (a) Clustering dendrogram and (b) ordination plot illustrating the similarity between stations from all three seasons in terms of zooplankton composition. The shades of grey indicate the final separation of samples into aggregation groups. Abbreviations: A, autumn; S, summer; Sp, spring.

Table 2 Average percentage dissimilarity of zooplankton communities between groupings of stations obtained with the CLUSTER and MDS analyses.

\begin{tabular}{llcccc}
\hline Average dissimilarity (\%) & Spring & Summer/autumn shelf \& open sea & Summer/autumn inner basin & Summer fjord & Autumn fjord \\
\hline Summer/autumn shelf \& open sea & 79.7 & - & - & - & - \\
Summer/autumn inner basin & 97.8 & 85.1 & - & - & - \\
Summer fjord & 93.5 & 60.0 & 59.4 & - \\
Autumn fjord & 93.9 & 66.0 & 50.3 & 41.7 \\
\hline
\end{tabular}

highest at station $\mathrm{K} 2$, with 275 ind. $\mathrm{m}^{-3}$, whereas at station $\mathrm{Kl}$ it was only 192 ind. $\mathrm{m}^{-3}$.

In summer and autumn, the highest abundance was observed at station $\mathrm{K} 5$ (inner fjord basin), reaching 8270 and 10560 ind. $\mathrm{m}^{-3}$, respectively. The abundance was lower in the central part of the fjord in both seasons, and decreased further towards the shelf stations.
Only a few taxa occurred frequently and were relatively abundant, comprising the vast part of the zooplankton abundance from fjord to shelf (Table 5). They included: C. finmarchicus, C. glacialis, M. longa, Pseudocalanus spp., O. similis, Microcalanus spp., Triconia (= Oncaea) borealis, Cirripedia nauplii and Echinodermata larvae, and the detailed patterns of seasonal and spatial variability are only discussed for these taxa. 
Table 3 Mean abundance (ab; ind. $\mathrm{m}^{-3}$ ) and percentage contribution (\%) of individual taxa to the zooplankton similarities in the obtained groupings, calculated with similarity percentage (SIMPER) analysis. The values in bold indicate taxa accounting for approximately $90 \%$ of the similarity in each grouping.

\begin{tabular}{|c|c|c|c|c|c|c|c|c|c|c|}
\hline \multirow[b]{2}{*}{ Taxon } & \multicolumn{2}{|c|}{ Autumn fjord } & \multicolumn{2}{|c|}{ Summer fjord } & \multicolumn{2}{|c|}{$\begin{array}{l}\text { Summer/autumn } \\
\text { inner basin }\end{array}$} & \multicolumn{2}{|c|}{$\begin{array}{l}\text { Summerlautumn } \\
\text { shelf \& open sea }\end{array}$} & \multicolumn{2}{|l|}{ Spring } \\
\hline & $a b$ & $\%$ & $a b$ & $\%$ & $a b$ & $\%$ & $a b$ & $\%$ & $a b$ & $\%$ \\
\hline Foraminifera & 0.1 & 0.0 & 0.0 & 0.0 & 0.0 & 0.0 & 1.2 & 0.1 & 0.3 & 0.1 \\
\hline Aglantha digitale & 0.8 & 0.0 & 0.5 & 0.0 & 1.9 & 0.0 & 1.5 & 0.2 & 0.0 & 0.0 \\
\hline Beroë cucumis & 0.1 & 0.0 & 0.1 & 0.0 & 0.3 & 0.0 & 0.15 & 0.0 & 0.1 & 0.1 \\
\hline Polychaeta-larvae & 0.5 & 0.0 & 1.9 & 0.0 & 1.6 & 0.0 & 0.4 & 0.0 & 0.3 & 0.1 \\
\hline Ostracoda & 0.1 & 0.0 & 0.2 & 0.0 & 0.1 & 0.0 & 4.7 & 0.3 & 0.2 & 0.2 \\
\hline Cirripedia-larvae & 3.6 & 0.1 & 1.2 & 0.0 & 0.2 & 0.0 & 0.0 & 0.0 & 269.4 & 0.9 \\
\hline Acartia longiremis & 4.0 & 0.1 & 1.8 & 0.1 & 36.4 & 0.4 & 0.8 & 0.0 & 0.1 & 0.0 \\
\hline Bradyidius similis & 3.8 & 0.1 & 1.2 & 0.0 & 0.3 & 0.0 & 0.0 & 0.0 & 0.1 & 0.0 \\
\hline Calanus finmarchicus & 87.7 & 2.4 & 145 & 5.0 & 183 & 1.3 & 118 & 19.8 & 12.8 & 13.5 \\
\hline Calanus glacialis & 18.4 & 0.6 & 48.2 & 1.6 & 70.5 & 0.7 & 17.4 & 0.9 & 3.3 & 2.1 \\
\hline Calanus hyperboreus & 9.6 & 0.3 & 12.5 & 0.4 & 20.7 & 0.2 & 0.9 & 0.1 & 0.0 & 0.1 \\
\hline Metridia longa & 18.0 & 0.5 & 42.0 & 1.0 & 5.1 & 0.1 & 12.4 & 1.8 & 1.8 & 1.5 \\
\hline Microcalanus spp. & 67.5 & 2.1 & 44.1 & 1.3 & 186 & 0.8 & 26.7 & 1.3 & 6.0 & 3.8 \\
\hline Oithona atlantica & 37.3 & 1.1 & 29.8 & 1.0 & 60.6 & 0.6 & 13.9 & 1.2 & 0.5 & 0.5 \\
\hline Oithona similis & 2494 & 80.0 & 1289 & 45.0 & 4946 & 64.7 & 455 & 62.5 & 62.5 & 56.7 \\
\hline Paraeuch. norvegica & 0.1 & 0.0 & 0.1 & 0.0 & 0.0 & 0.0 & 1.2 & 0.1 & 0.0 & 0.0 \\
\hline Pseudocalanus spp. & 124 & 4.0 & 188 & 5.4 & 1804 & 22.6 & 22.2 & 2.8 & 8.3 & 7.8 \\
\hline Triconia borealis & 143 & 4.6 & 134 & 4.7 & 337 & 2.1 & 42.9 & 1.5 & 0.5 & 0.1 \\
\hline Calanoida nauplii & 15.0 & 0.5 & 188 & 4.9 & 286 & 0.3 & 79.0 & 4.1 & 7.3 & 11.1 \\
\hline Harpacticoida n. det. & 0.4 & 0.0 & 0.4 & 0.0 & 0.4 & 0.0 & 0.1 & 0.0 & 0.3 & 0.1 \\
\hline Themisto abyssorum & 0.2 & 0.0 & 0.8 & 0.0 & 0.52 & 0.0 & 0.5 & 0.1 & 0.4 & 0.2 \\
\hline Thysanoessa longicaudata & 0.0 & 0.0 & 0.0 & 0.0 & 0.51 & 0.0 & 0.4 & 0.1 & 0.1 & 0.1 \\
\hline Clione limacina & 0.4 & 0.0 & 0.0 & 0.0 & 1.7 & 0.0 & 0.1 & 0.0 & 0.4 & 0.3 \\
\hline Limacina helicina & 119 & 3.1 & 62.9 & 1.9 & 252 & 2.5 & 0.3 & 0.7 & 0.1 & 0.1 \\
\hline Bivalvia-larvae & 9.2 & 0.2 & 21.7 & 0.7 & 491 & 3.3 & 6.5 & 0.7 & 0.0 & 0.0 \\
\hline Echinodermata larvae & 5.8 & 0.2 & 800 & 24.5 & 637 & 0.5 & 7.9 & 0.1 & 0.0 & 0.0 \\
\hline Eukrohnia hamata & 4.0 & 0.1 & 3.9 & 0.1 & 0.2 & 0.0 & 6.3 & 1.2 & 0.3 & 0.4 \\
\hline Sagitta elegans & 0.7 & 0.0 & 1.7 & 0.1 & 5.2 & 0.1 & 0.1 & 0.0 & 0.4 & 0.2 \\
\hline Oikopleura spp. & 2.0 & 0.0 & 1.7 & 0.0 & 0.1 & 0.0 & 4.5 & 0.2 & 0.1 & 0.1 \\
\hline Fritillaria borealis & 4.1 & 0.1 & 85.0 & 2.2 & 70.1 & 0.1 & 11.6 & 0.1 & 0.2 & 0.0 \\
\hline
\end{tabular}

\section{Calanus finmarchicus}

In spring, C. finmarchicus was barely present within the fjord ( $<13$ ind. $\mathrm{m}^{-3}$ in the surface layer at K2), but occurred in relatively high densities on the shelf (station V10) and in the open sea (station V6) (Fig. 5). At these two outer stations, the bulk of the C. finmarchicus population was concentrated close to the surface, with 137 and 109 ind. $\mathrm{m}^{-3}$ in the uppermost layers, respectively. The population was predominated by adult females and males, with a considerable share of copepodid stage V (Fig. 6).

In contrast to the situation in spring, $C$. finmarchicus was much more abundant both outside and inside the fjord during the summer and autumn. It was mostly concentrated in the surface layer, although relatively high densities were also recorded in the deep layers in autumn. Again, the highest abundances were recorded at station V10, reaching 2490 ind. $\mathrm{m}^{-3}$ during summer and
1140 ind. $\mathrm{m}^{-3}$ during autumn. In summer, C. finmarchicus was also relatively abundant in the subsurface layer, with the highest density observed at station K5 (461 ind. $\mathrm{m}^{-3}$ ). In autumn, part of the $C$. finmarchicus population had descended to near the bottom (up to 251 ind. $\mathrm{m}^{-3}$ in the bottom layer at station K0). During the summer, the population was composed of predominantly copepodid stages I and II in the surface and subsurface layers at all stations, except for station V6, whereas CVs occurred in deeper layers. A more advanced developmental situation in summer, with a high number of CIII, followed by CI and CII, occurred at the outer station V6 (Fig. 7). In autumn, the older stages CIV and CV predominated the open water at all depths (Fig. 8). Inside the fjord, CV was the prevailing stage in the bottom layer, whereas CII and CIII were still the main stages in the surface layer. However, at station K5 (inner glacial bay), the most abundant copepodid stages in the surface layer were III and IV. 
Table 4 Taxa recorded during three seasons in Kongsfjorden, 2002.

\begin{tabular}{|c|c|}
\hline \multicolumn{2}{|l|}{ Foraminifera } \\
\hline & Stephos lamellatus Sars, 1902 \\
\hline Hydrozoa (medusae): & $\begin{array}{l}\text { Temora longicornis (Müller, } \\
\text { 1792) }\end{array}$ \\
\hline Aglantha digitale (Müller, 1776) & $\begin{array}{l}\text { Triconia (Oncaea) borealis } \\
\quad \text { (Sars, 1918) }\end{array}$ \\
\hline Sarsia princeps (Haeckel, 1879) & $\begin{array}{l}\text { Xantharus siedleckii Schulz } \\
\text { \& Kwasniewski, } 2004\end{array}$ \\
\hline Siphonophora: & Cyclopoida, not determined \\
\hline \multicolumn{2}{|l|}{ Dimophyes arctica (Chun, 1897) } \\
\hline \multicolumn{2}{|l|}{ Ctenophora: } \\
\hline \multicolumn{2}{|l|}{ Mertensia ovum (Fabricius, 1780) } \\
\hline & Cladocera: \\
\hline Nematoda & $\begin{array}{l}\text { Evadne nordmanni Lovén, } 1836 \\
\text { Podon leuckartii Sars, } 1862\end{array}$ \\
\hline \multicolumn{2}{|l|}{ Polychaeta—larvae } \\
\hline & Isopoda \\
\hline \multicolumn{2}{|l|}{ Ostracoda } \\
\hline & Cumacea \\
\hline \multicolumn{2}{|l|}{ Cirripedia—larvae } \\
\hline & Tanaidacea \\
\hline \multicolumn{2}{|l|}{ Copepoda: } \\
\hline Acartia longiremis (Lilljeborg, 1853) & Amphipoda: \\
\hline Aetideus armatus (Boeck, 1872) & $\begin{array}{l}\text { Themisto abyssorum Boeck, } \\
1870\end{array}$ \\
\hline Aetideopsis rostrata Sars, 1903 & $\begin{array}{l}\text { Themisto libellula (Lichtenstein, } \\
\text { 1822) }\end{array}$ \\
\hline \multicolumn{2}{|l|}{$\begin{array}{l}\text { Anomalocera patersoni Templeton, } \\
1837\end{array}$} \\
\hline Bradyidius similis (Sars, 1902) & Euphausiacea: \\
\hline Calanus finmarchicus (Gunnerus, 1756) & $\begin{array}{l}\text { Thysanoessa inermis (Krøyer, } \\
\text { 1846) }\end{array}$ \\
\hline Calanus glacialis Jaschnov, 1955 & $\begin{array}{l}\text { Thysanoessa longicaudata } \\
\text { (Krøyer, 1846) }\end{array}$ \\
\hline \multicolumn{2}{|l|}{ Calanus hyperboreus (Krøyer, 1838) } \\
\hline Centropages hamatus (Lilljeborg, 1853) & Decapoda-larvae \\
\hline \multicolumn{2}{|c|}{ Chiridius obtusifrons Sars, 1902} \\
\hline Gaetanus tenuispinus (Sars, 1900) & Clione limacina (Phipps, 1774) \\
\hline $\begin{array}{l}\text { Heterorhabdus norvegicus (Boeck, } \\
\text { 1872) }\end{array}$ & Limacina helicina Phipps, 1774 \\
\hline Metridia lucens Boeck, 1864 & $\begin{array}{l}\text { Limacina retroversa (Fleming, } \\
\text { 1823) }\end{array}$ \\
\hline \multicolumn{2}{|l|}{ Metridia longa (Lubbock, 1854) } \\
\hline $\begin{array}{l}\text { Mesaiokeras spitsbergensis Schulz \& } \\
\quad \text { Kwasniewski, } 2004\end{array}$ & Bivalvia-larvae \\
\hline \multicolumn{2}{|l|}{ Microcalanus spp. } \\
\hline $\begin{array}{l}\text { Neoscolecithrix farrani Smirnov, } 1935 \\
\text { Oithona atlantica Farran, } 1908\end{array}$ & Bryozoa-larvae \\
\hline Oithona similis Claus, 1863 & Echinodermata_larvae \\
\hline \multicolumn{2}{|l|}{ Paracalanus parvus Claus, 1863} \\
\hline Paraeuchaeta barbata (Brady,1883) & Chaetognatha: \\
\hline Paraeuchaeta glacialis (Hansen, 1887) & $\begin{array}{l}\text { Eukrohnia hamata (Möbius, } \\
\text { 1875) }\end{array}$ \\
\hline Paraeuchaeta norvegica (Boeck, 1865) & Sagitta elegans Verrill, 1873 \\
\hline \multicolumn{2}{|l|}{$\begin{array}{l}\text { Pseudocalanus acuspes (Giesbrecht, } \\
\text { 1881) }\end{array}$} \\
\hline Pseudocalanus minutus (Krøyer, 1845) & Appendicularia: \\
\hline Scaphocalanus brevicornis (Sars, 1900) & Oikopleura spp. \\
\hline Scolecithricella minor (Brady, 1883) & $\begin{array}{l}\text { Fritillaria borealis Lohmann, } \\
\quad 1896\end{array}$ \\
\hline Spinocalanus abyssalis Giesbrecht, 1888 & \\
\hline
\end{tabular}

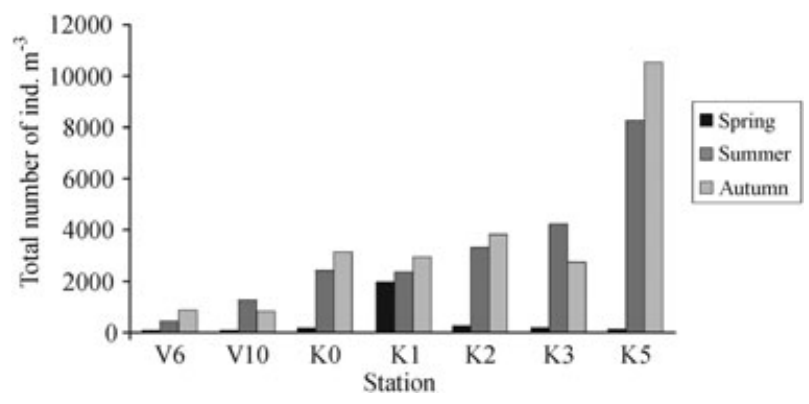

Fig. 4 Total zooplankton abundance (ind. $\mathrm{m}^{-3}$ ) at stations ranging from the open sea (station V6) to inner Kongsfjorden (station K5) during three seasons in 2002.

\section{Calanus glacialis}

In spring, C. glacialis was scarce at almost all of the stations investigated (Fig. 9). At stations K5 (mean for the entire 90-m water column) and K2 (subsurface layer), the abundance reached 11 and 12 ind. $\mathrm{m}^{-3}$, respectively. Copepodid stage $\mathrm{V}$ prevailed in the glacial bay, whereas adult females dominated at station K2 (Fig. 6).

A very different situation was observed during the summer, when C. glacialis were concentrated in the surface layer. The highest abundance of this copepod was in the surface layer at station V10, situated outside of the fjord (774 ind. $\mathrm{m}^{-3}$ ), but this decreased considerably further out into the open water $\left(27\right.$ ind. $\mathrm{m}^{-3}$ at station V6). Within the fjord, the abundance in the surface layer ranged from 124 ind. $\mathrm{m}^{-3}$ (station $\mathrm{Kl}$ ) to 423 ind. $\mathrm{m}^{-3}$ (K3), but was only $10-20 \%$ of this value deeper in the water column. At the inner bay station K5, C. glacialis was more evenly distributed in the water column, with 177 ind. $\mathrm{m}^{-3}$ in the surface layer and 131 ind. $\mathrm{m}^{-3}$ in the layer below. Copepodid stage I was the most common stage in the surface layers of the outer stations (V6 and V10), as well as at the stations in the main fjord basin (K0 and $\mathrm{K} 3$ ), whereas stages $\mathrm{CV}$ and $\mathrm{CIV}$ were predominant at the other fjord stations (K1, K2 and K5) (Fig. 7).

In autumn, C. glacialis occurred at much lower densities, and was mainly concentrated close to the bottom, with the maximum abundance found in the glacial bay $\left(142\right.$ ind. $\left.\mathrm{m}^{-3}\right)$. Copepodid stage $\mathrm{V}$ predominated in the population (Fig. 8).

\section{Calanus hyperboreus}

In spring, C. hyperboreus was hardly present at any station (Fig. 10). In summer, it was recorded in the highest numbers inside the fjord (up to 58 ind. $\mathrm{m}^{-3}$ at station K2), where it was concentrated in the bottom layers. An exception was the situation at the station $\mathrm{K} 5$, where $C$. hyperboreus was relatively abundant (21-42 ind. $\left.\mathrm{m}^{-3}\right)$ in 
Table 5 Relative abundance (\%) of zooplankton taxa in Kongsfjorden during spring, summer and autumn.

\begin{tabular}{|c|c|c|c|c|c|c|c|}
\hline \multicolumn{8}{|l|}{ Spring } \\
\hline Taxonlstation & V6 & V10 & KO & K1 & K2 & K3 & K5 \\
\hline Calanus finmarchicus & 55.22 & 47.24 & 2.45 & 0.23 & 3.99 & 1.72 & 8.73 \\
\hline Calanus glacialis & 0.60 & 0.74 & 1.00 & 0.07 & 3.26 & 1.03 & 10.88 \\
\hline Calanus hyperboreus & 0.09 & 0.00 & 0.03 & 0.00 & 0.00 & 0.05 & 0.06 \\
\hline Pseudocalanus spp. & 1.79 & 2.33 & 8.37 & 0.79 & 5.33 & 3.79 & 12.34 \\
\hline Metridia longa & 6.03 & 7.72 & 0.43 & 0.00 & 0.11 & 0.47 & 0.34 \\
\hline Oithona similis & 5.68 & 28.91 & 31.67 & 2.85 & 70.87 & 80.45 & 49.43 \\
\hline Microcalanus spp. & 1.78 & 0.21 & 1.48 & 0.27 & 8.10 & 8.76 & 5.21 \\
\hline Triconia (O.) borealis & 0.00 & 0.00 & 0.24 & 0.00 & 0.00 & 0.06 & 2.64 \\
\hline Cirripedia nauplii & 0.01 & 0.21 & 43.29 & 95.05 & 0.01 & 0.00 & 0.00 \\
\hline Echinodermata larvae & 0.00 & 0.00 & 0.01 & 0.00 & 0.02 & 0.00 & 0.00 \\
\hline Others & 28.80 & 12.62 & 11.05 & 0.74 & 8.32 & 3.67 & 10.37 \\
\hline \multicolumn{8}{|l|}{ Summer } \\
\hline Taxonlstation & V6 & V10 & KO & K1 & K2 & K3 & K5 \\
\hline Calanus finmarchicus & 20.63 & 13.32 & 6.04 & 3.90 & 4.47 & 4.47 & 3.46 \\
\hline Calanus glacialis & 0.61 & 4.10 & 1.72 & 1.33 & 1.59 & 1.57 & 1.21 \\
\hline Calanus hyperboreus & 0.14 & 0.06 & 0.67 & 0.42 & 0.49 & 0.18 & 0.39 \\
\hline Pseudocalanus spp. & 2.66 & 1.74 & 5.70 & 3.95 & 7.18 & 6.63 & 16.58 \\
\hline Metridia longa & 1.57 & 1.24 & 3.65 & 0.93 & 1.25 & 0.40 & 0.06 \\
\hline Oithona similis & 41.46 & 51.44 & 40.85 & 44.29 & 42.22 & 40.25 & 47.50 \\
\hline Microcalanus spp. & 0.08 & 0.30 & 2.45 & 0.72 & 1.94 & 0.82 & 0.60 \\
\hline Triconia (O.) borealis & 0.73 & 0.85 & 6.46 & 4.22 & 5.09 & 2.57 & 1.51 \\
\hline Cirripedia nauplii & 0.00 & 0.00 & 0.00 & 0.00 & 0.00 & 0.00 & 0.00 \\
\hline Echinodermata larvae & 0.38 & 2.20 & 17.11 & 33.10 & 22.30 & 28.63 & 15.05 \\
\hline Others & 31.74 & 24.75 & 15.34 & 7.14 & 13.48 & 14.50 & 13.64 \\
\hline \multicolumn{8}{|l|}{ Autumn } \\
\hline Taxonlstation & V6 & V10 & KO & K1 & K2 & K3 & K5 \\
\hline Calanus finmarchicus & 14.68 & 10.17 & 4.09 & 2.42 & 2.44 & 2.04 & 0.77 \\
\hline Calanus glacialis & 0.73 & 0.69 & 0.75 & 0.52 & 0.45 & 0.63 & 0.38 \\
\hline Calanus hyperboreus & 0.23 & 0.04 & 0.43 & 0.27 & 0.26 & 0.26 & 0.09 \\
\hline Pseudocalanus spp. & 5.14 & 1.31 & 3.23 & 4.15 & 3.72 & 4.55 & 21.18 \\
\hline Metridia longa & 2.25 & 1.04 & 0.78 & 0.72 & 0.30 & 0.53 & 0.05 \\
\hline Oithona similis & 45.95 & 68.13 & 74.34 & 77.72 & 81.42 & 79.45 & 56.50 \\
\hline Microcalanus spp. & 8.51 & 3.61 & 2.65 & 1.87 & 1.88 & 2.09 & 3.06 \\
\hline Triconia (O.) borealis & 17.13 & 1.43 & 3.92 & 5.56 & 4.18 & 4.42 & 5.20 \\
\hline Cirripedia nauplii & 0.00 & 0.06 & 0.09 & 0.01 & 0.05 & 0.00 & 0.00 \\
\hline Echinodermata larvae & 0.04 & 0.04 & 0.24 & 0.29 & 0.10 & 0.13 & 0.28 \\
\hline Others & 5.36 & 13.48 & 9.48 & 6.46 & 5.19 & 5.90 & 12.49 \\
\hline
\end{tabular}

the entire water column. It was scarce outside of the fjord (stations V10 and V6). The bulk of the population consisted of copepodid stage IV (Fig. 7).

In autumn, the distribution and age structure of $C$. hyperboreus were very similar to those observed during the summer. The densities of copepods in the bottom layers were comparable with the summer values, but there were fewer copepods in the upper layers. Unlike the summer situation, C. hyperboreus was concentrated in the deeper layers at station K5, rather than being more dispersed in the water column. In autumn, the prevailing stage was still CIV (Fig. 8).

\section{Pseudocalanus spp.}

Because of the difficulties in identifying the two Pseudocalanus species for all copepodid stages during routine sample examination, the description of the seasonal and spatial distribution of these copepods was only carried out to the generic level.

In spring, Pseudocalanus was rarely present at the outer stations (Fig. 11). Within the fjord, representatives of this genus were relatively abundant in the surface layer at station $\mathrm{K} 0$ (79 ind. $\mathrm{m}^{-3}$ ), but were less abundant $\left(<27\right.$ ind. $\left.\mathrm{m}^{-3}\right)$ at the other stations. During spring, the 

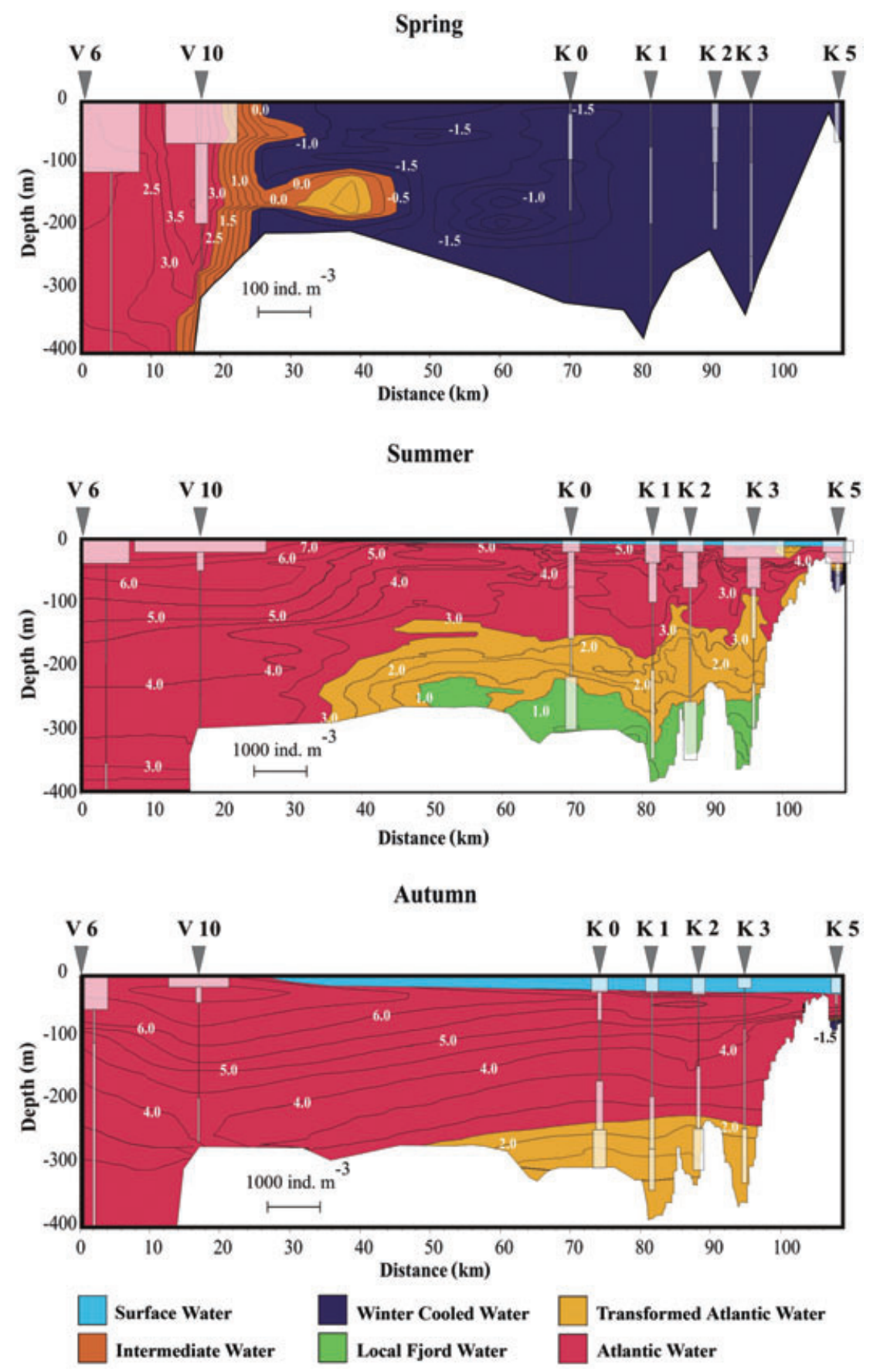

Fig. 5 Seasonal changes of Calanus finmarchicus abundance (white rectangles; ind. $\mathrm{m}^{-3}$ ) along the transect running from the open sea into Kongsfjorden. Note that there is a different abundance scale for each season.
Pseudocalanus population was mainly composed of copepodid stages III-V (Fig. 6).

In summer, the abundance of Pseudocalanus was generally much higher, and it increased from the shelf into the fjord. Individuals of Pseudocalanus were concentrated predominantly in the surface and subsurface layers, reaching the highest abundances in the glacier bay (2500 and 2100 ind. $\mathrm{m}^{-3}$, respectively). The age structure was different from that observed in the spring, as the younger stages (CI-CIII) were the most abundant, although CV prevailed in the deep and bottom layers (Fig. 7).

In autumn, the bulk of Pseudocalanus were concentrated in the bottom layers, although part of the population remained closer to the surface. Again, the highest concentrations were recorded at station K5, with 1040 ind. $\mathrm{m}^{-3}$ in the surface layer, and up to 5560 ind. $\mathrm{m}^{-3}$ in the deep layer. In the central part of the fjord, the abundance of Pseudocalanus in the deep layers 

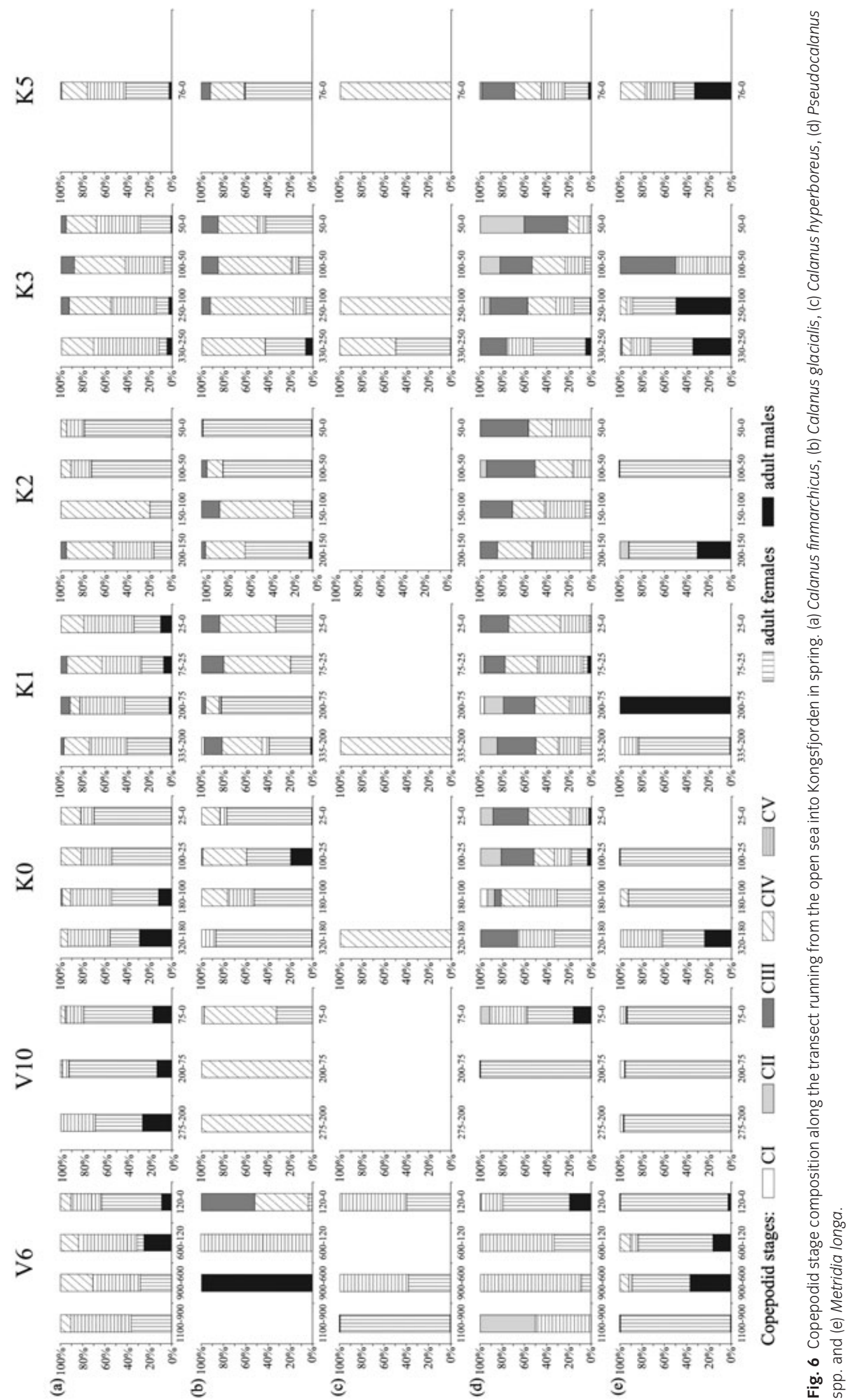


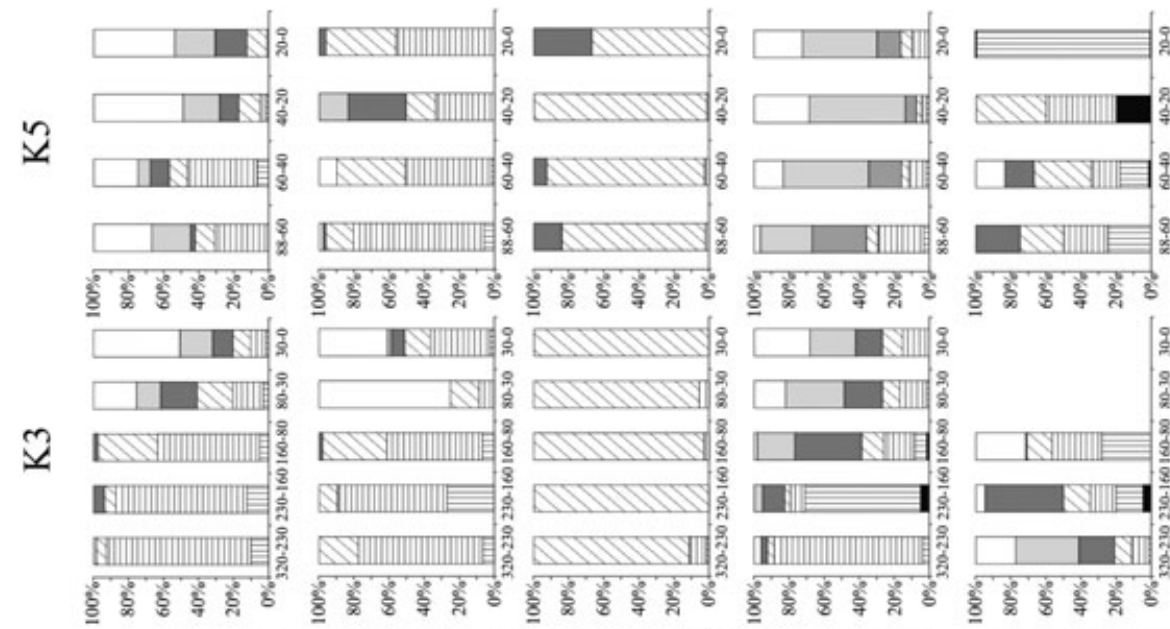

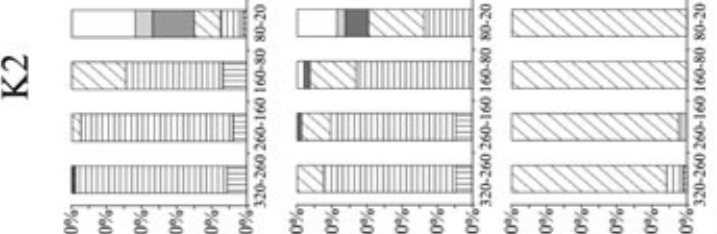
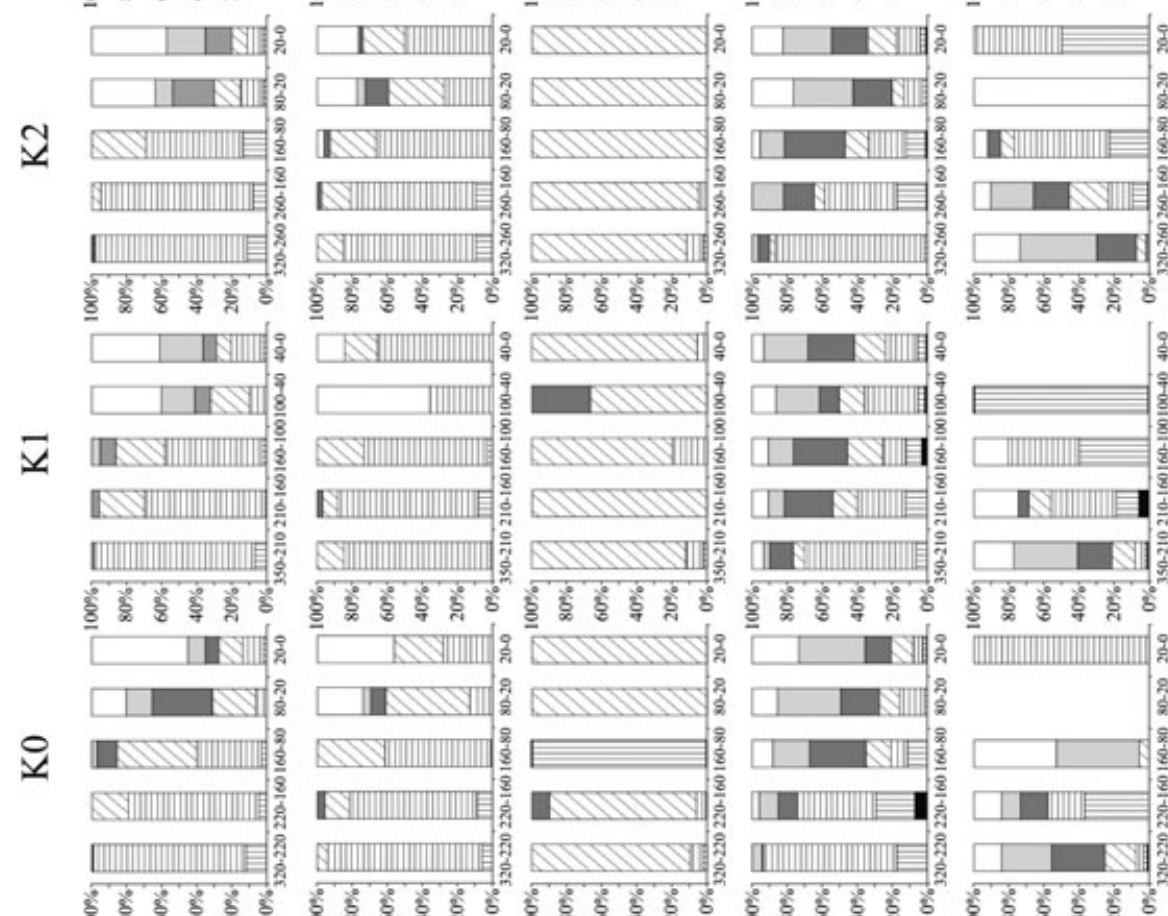

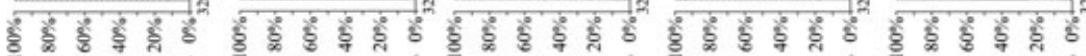

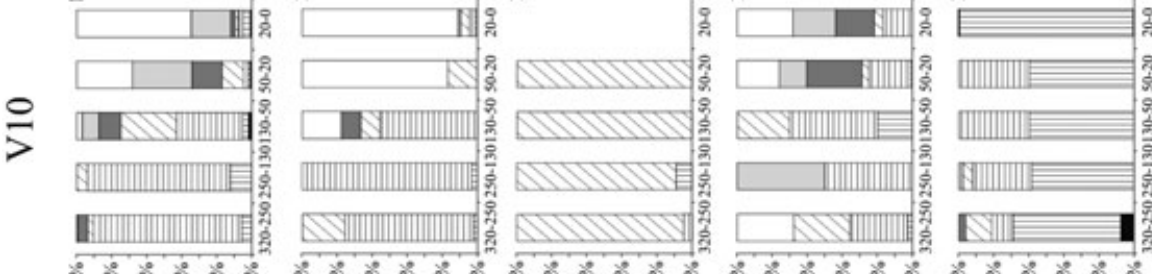

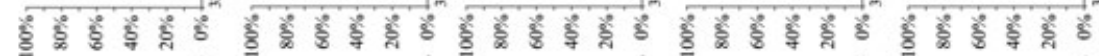

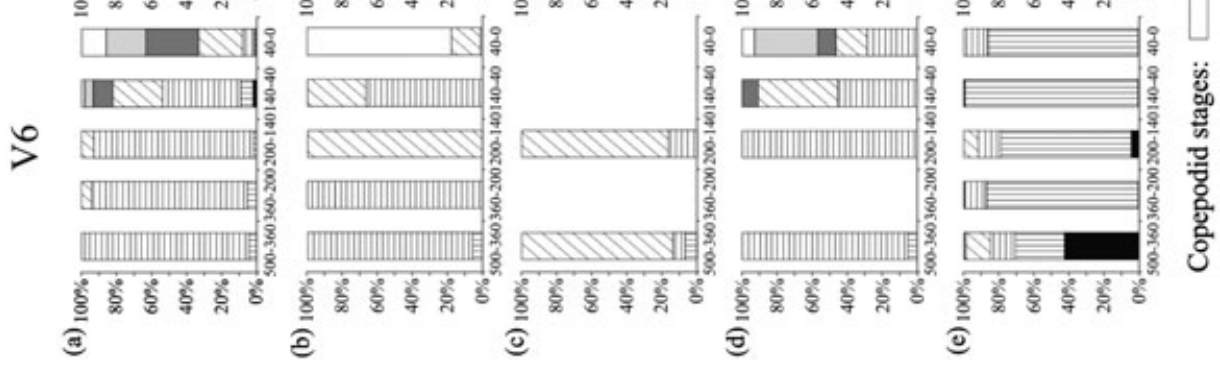




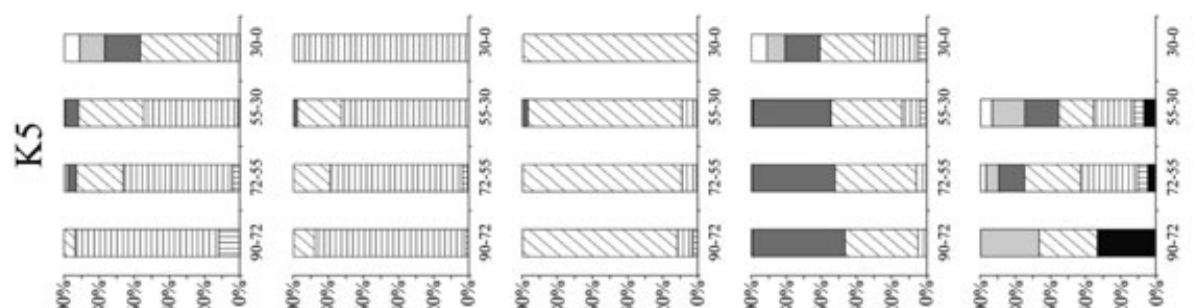



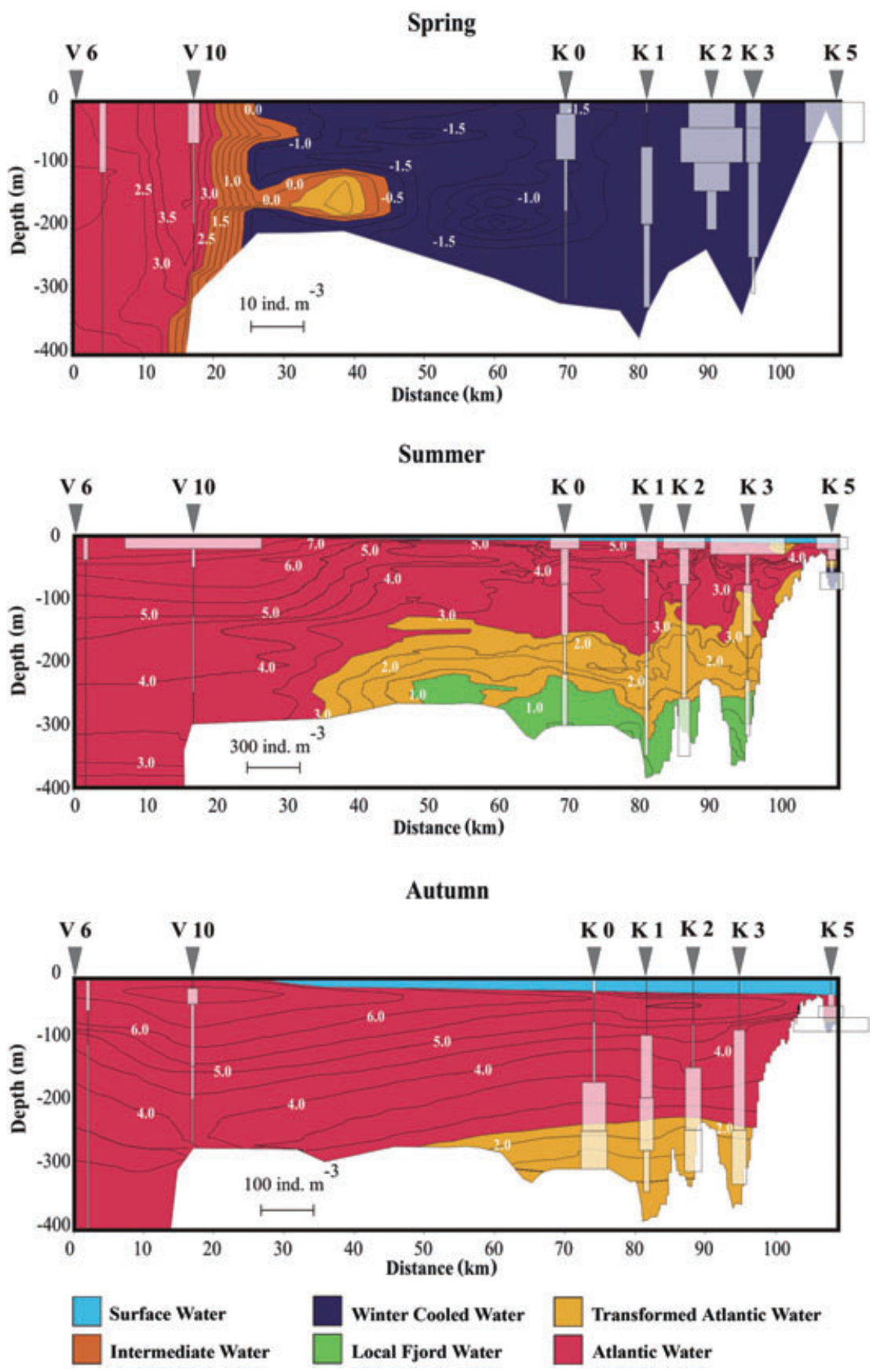

Fig. 9 Seasonal changes of Calanus glacialis abundance (white rectangles; ind. $\mathrm{m}^{-3}$ ) along the transect running from the open sea into Kongsfjorden. Note that there is a different abundance scale for each season. did not exceed 345 ind. $\mathrm{m}^{-3}$ (K2). At stations V10 and K2, there were even less Pseudocalanus in the surface layer (11 and 237 ind. $\mathrm{m}^{-3}$, respectively). The most abundant stages in autumn were CIII and CIV, followed by CV, although some CI and CII were still present near the surface (Fig. 8).

On a routine basis it was only possible to identify Pseudocalanus specimens to species level for adult (copepodid VI) females. The results of this examination show that most females in spring were Pseudocalanus minutus, whereas females of Pseudocalanus acuspes prevailed at all stations during summer and autumn, except for station $\mathrm{K} 5$ in summer.

\section{Metridia longa}

Similarly to the other copepods, $M$. longa was scarce in spring within the fjord, as well as over the shelf and in 

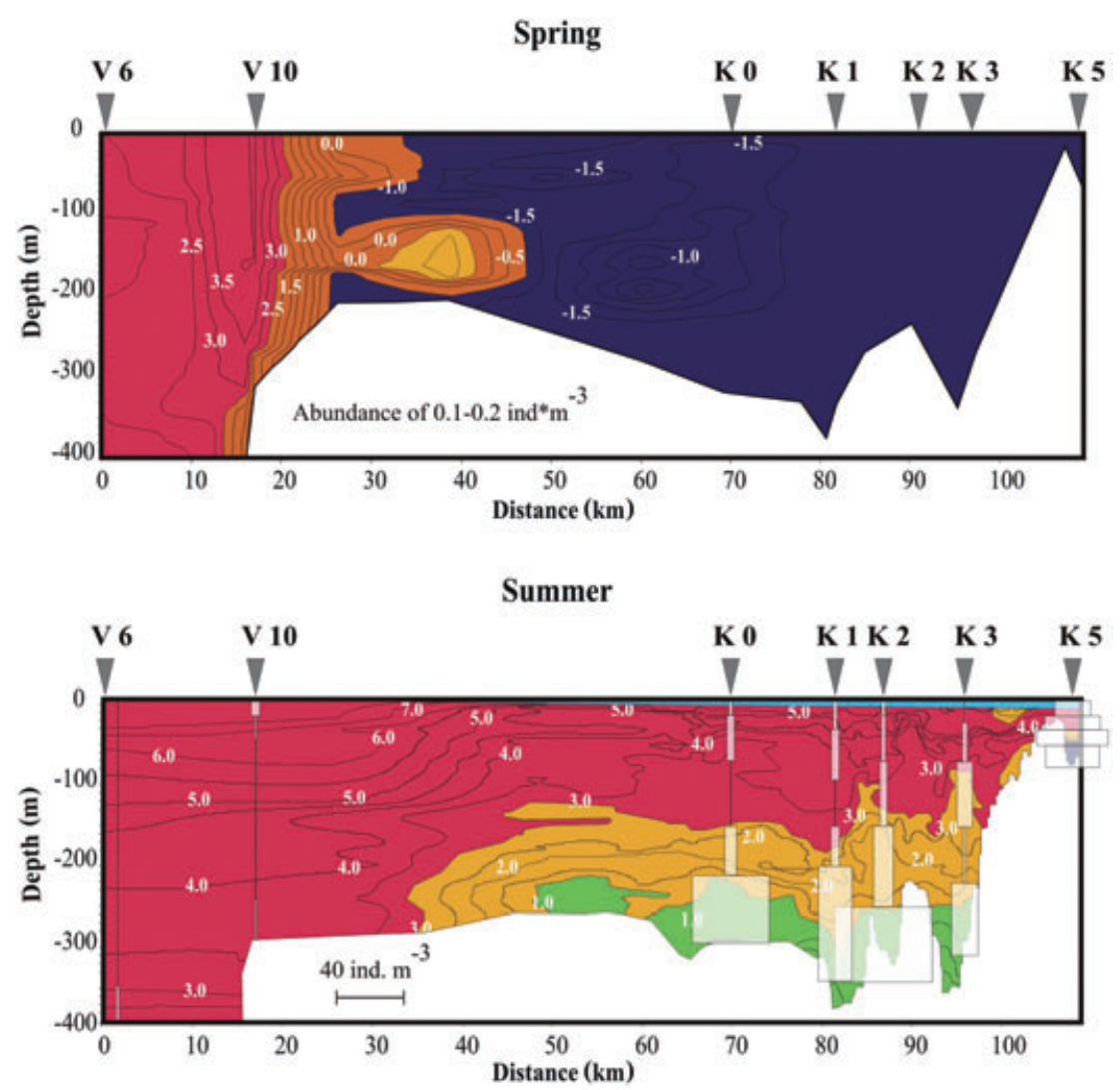

Fig. 10 Seasonal changes of Calanus hyperboreus abundance (white rectangles; ind. $\mathrm{m}^{-3}$ ) along the transect running from the open sea into Kongsfjorden. Note that there is a different abundance scale for each season.

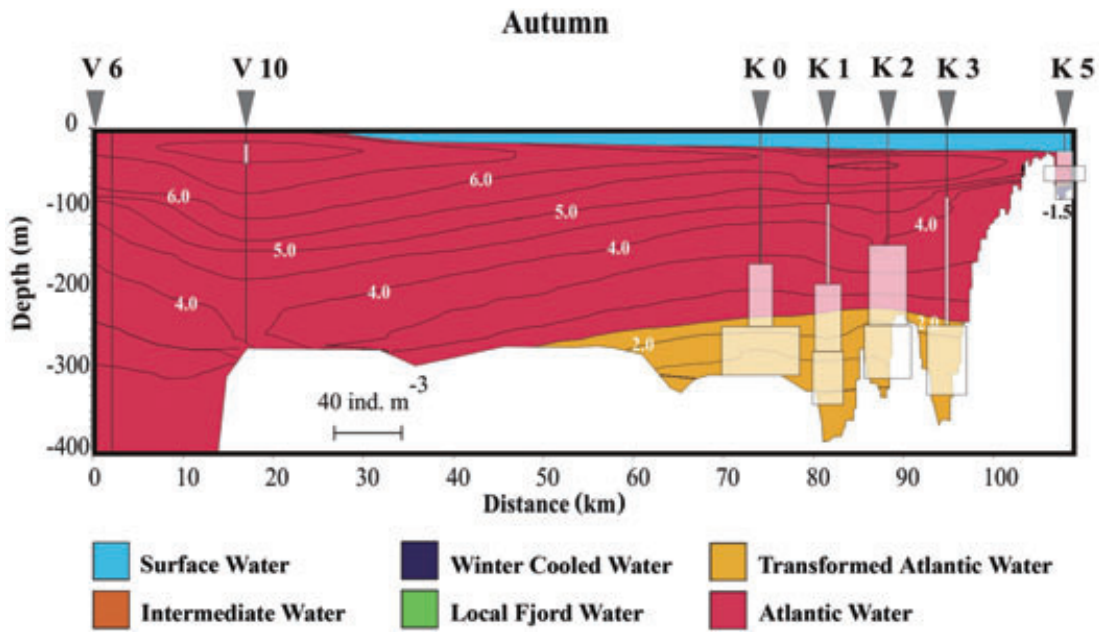

open water (Fig. 12). The highest abundance of this species was recorded in the surface layer at station V10 $\left(12\right.$ ind. $\left.\mathrm{m}^{-3}\right)$. The main copepodids present in spring were adult females, comprising $60 \%$ of the entire population (Fig. 6).

In summer, $M$. longa vanished from the surface, and its abundance increased mainly in the deeper parts of the water column, with $50-80$ ind. $\mathrm{m}^{-3}$. The species had the highest abundance in the deep parts of the outer basin (station K0, with 275 ind. $\mathrm{m}^{-3}$ ). The population consisted mostly of younger copepodid stages (I-III), with stage II prevailing (Fig. 7).

In autumn, $M$. longa was still less abundant outside of the fjord (with a maximum of $20-40$ ind. $\mathrm{m}^{-3}$ at $\mathrm{V} 10$ ) than in the main basin ( 55 and 47 ind. $\mathrm{m}^{-3}$ at $\mathrm{K} 0$, in the bottom and deep layers, respectively), and was mainly present close to the bottom. The predominant stages were $\mathrm{CV}$ and adult females outside the fjord, and CIV and CV in 

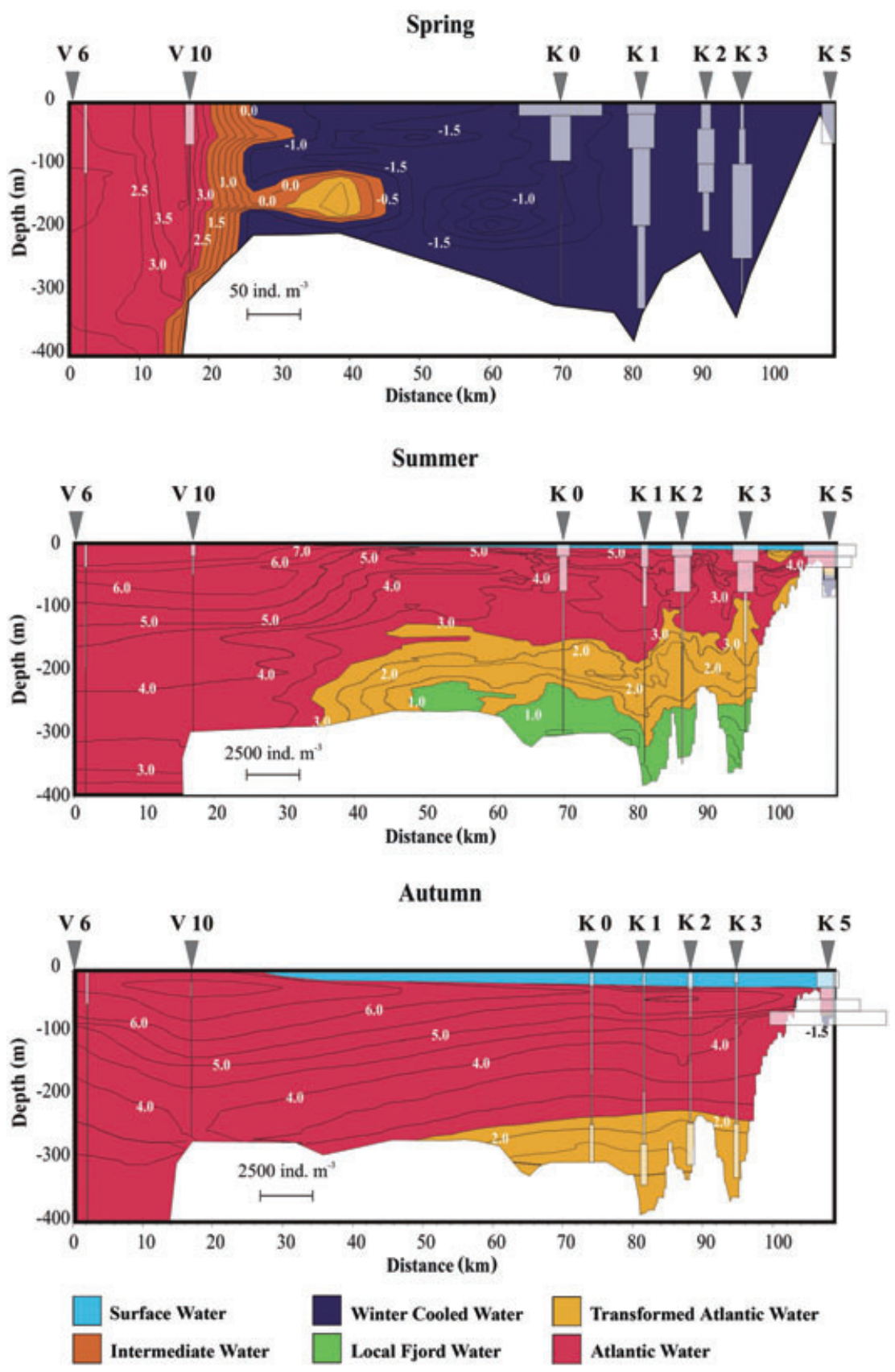

Fig. 11 Seasonal changes of Pseudocalanus spp. abundance (white rectangles; ind. $\mathrm{m}^{-3}$ ) along the transect running from the open sea into Kongsfjorden. Note that there is a different abundance scale in each season.
Kongsfjorden (Fig. 8). Metridia longa was never very abundant in the inner basin, with a maximum of 20 ind. $\mathrm{m}^{-3}$ in summer.

\section{Oithona similis}

Oithona similis was certainly the most numerous copepod species in this study. In spring, it prevailed in the upper layers of the water column, and reached 348 ind. $\mathrm{m}^{-3}$ in the surface layer at station $\mathrm{K} 3$, and was nearly as abun- dant $\left(266\right.$ ind $\left.\mathrm{m}^{-3}\right)$ in the subsurface layer at station $\mathrm{K} 2$ (Fig. 13). It was, however, less abundant in the open sea ( 11 ind. $\mathrm{m}^{-3}$ at station $\mathrm{V} 6$ ) and the glacial bay ( 50 ind. $\mathrm{m}^{-3}$ at station $\mathrm{K} 5$ ).

In summer, $O$. similis was more abundant than during the spring in the entire water column, with the highest densities in surface and subsurface layers. The highest abundance of the species was recorded in the surface layer at station $\mathrm{K} 3$ ( $10560 \mathrm{ind} . \mathrm{m}^{-3}$ ), and it was also numerous at station K2 (6860 ind. $\mathrm{m}^{-3}$ ). Its lowest abun- 

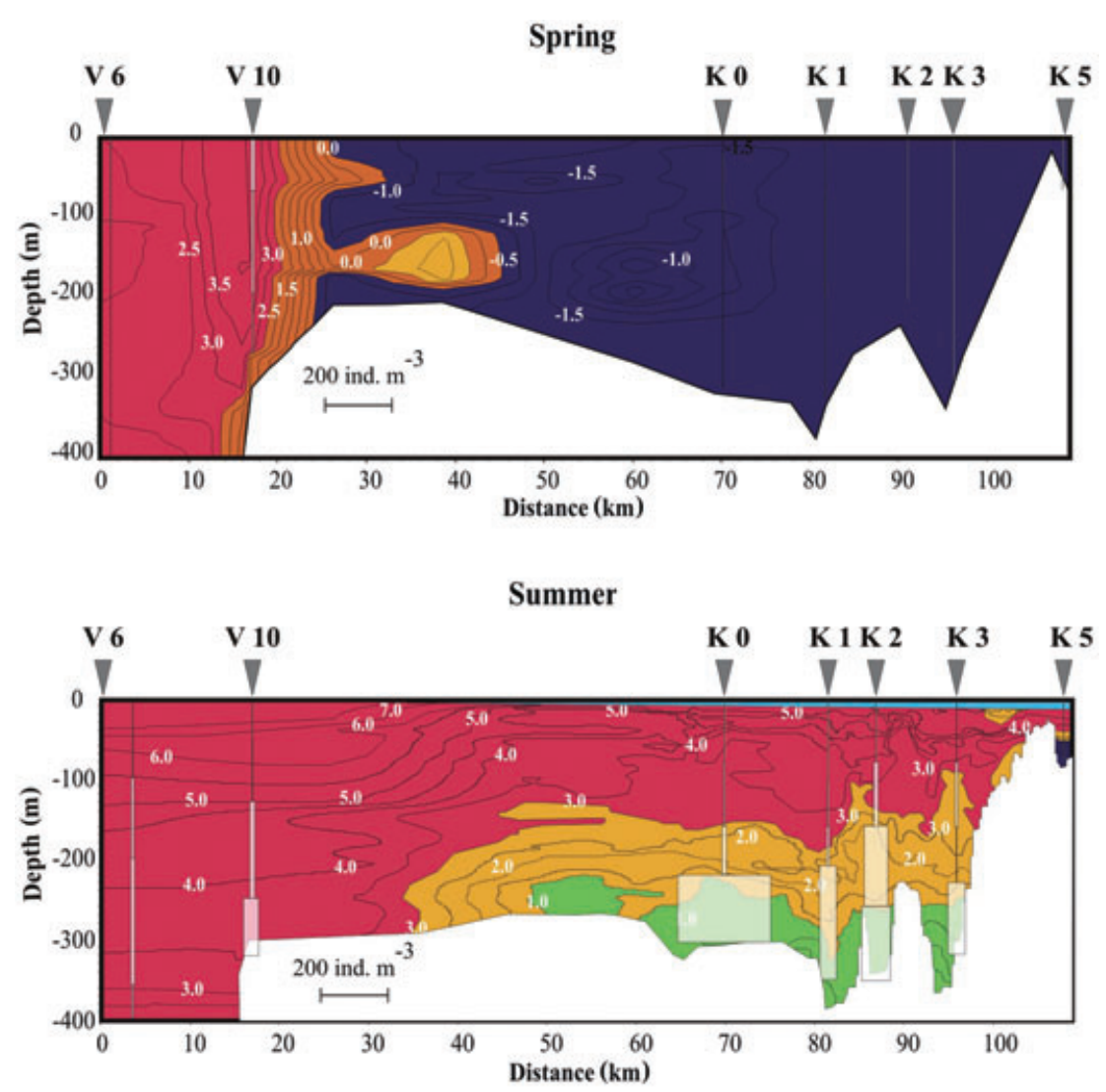

Fig. 12 Seasonal changes of Metridia longa abundance (white rectangles; ind. $\mathrm{m}^{-3}$ ) along the transect running from the open sea into Kongsfjorden.

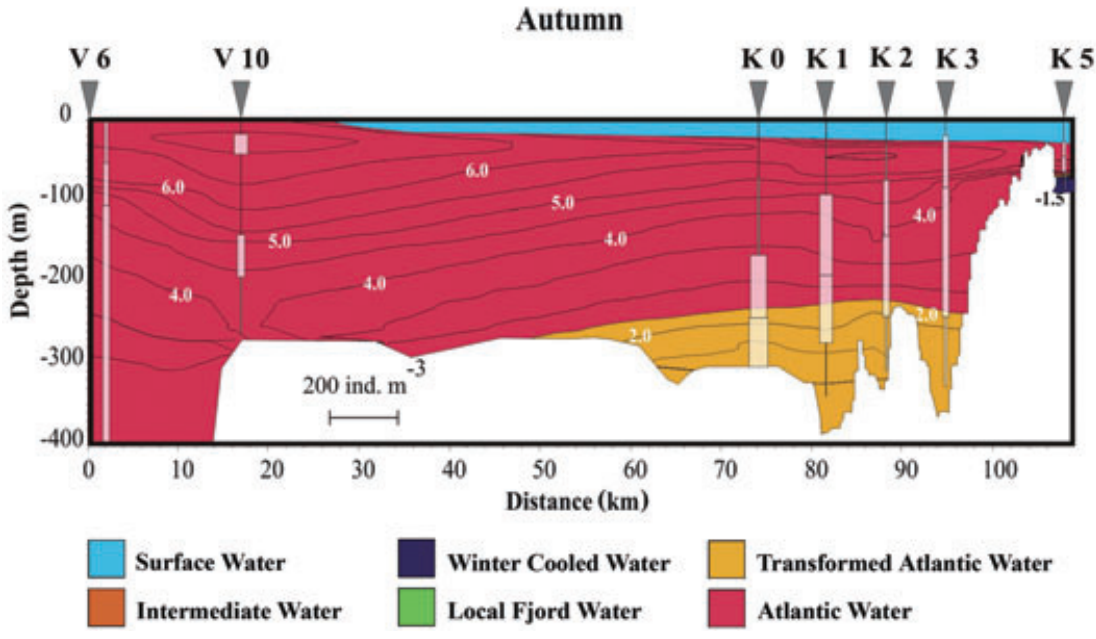

dance in the surface waters was recorded at station V6 $\left(1810\right.$ ind $\left.\mathrm{m}^{-3}\right)$. The abundance of $O$. similis was also high at station $\mathrm{K} 5$, with 7630 and 5850 ind. $\mathrm{m}^{-3}$ in the surface and subsurface layers, respectively. The species clearly avoided deep and bottom waters, as the highest abundance in these layers was only 296 ind. $\mathrm{m}^{-3}$, at station K5.

The abundance of $O$. similis in autumn was higher than in the two previous seasons. The species was still the most abundant in the surface and subsurface layers of the main fjord. Oithona similis reached the highest density recorded in this study (20 040 ind. $\mathrm{m}^{-3}$ ) in the surface layer at station $\mathrm{K} 2$, although it was also abundant at stations $\mathrm{K} 1$ and K3, with 15720 and 14940 ind. $\mathrm{m}^{-3}$, respectively. Similarly to other seasons, the abundance decreased towards the bottom, and the highest value in deep waters was only 3910 ind. $\mathrm{m}^{-3}$, in the bottom layer at station K5. 

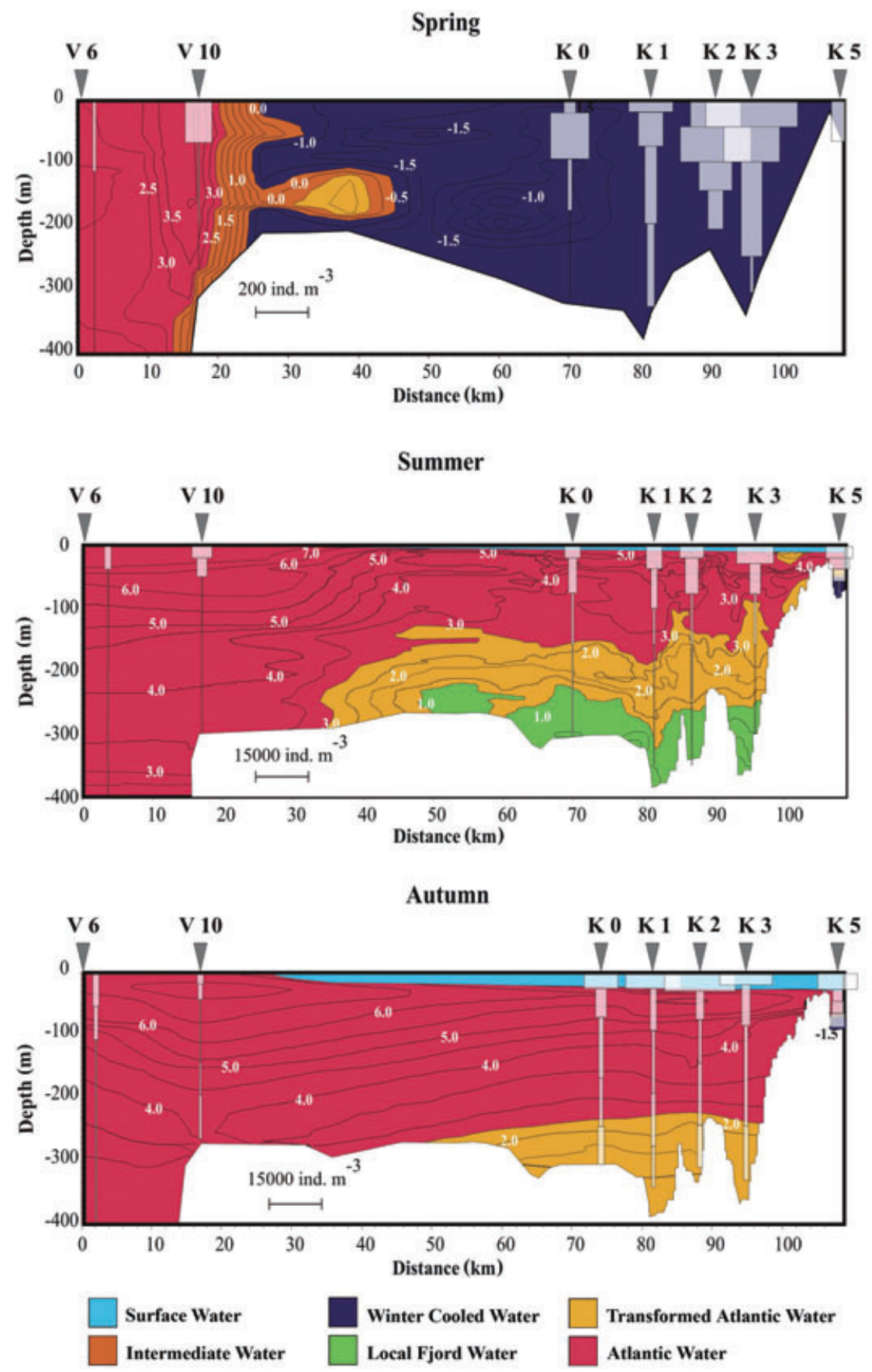

Fig. 13 Seasonal changes of Oithona similis abundance (white rectangles; ind. $\mathrm{m}^{-3}$ ) along the transect running from the open sea into Kongsfjorden. Note that there is a different abundance scale for each season.

\section{Microcalanus spp.}

Microcalanus (including Microcalanus pusillus and Microcalanus pygmaeus) occurred in very low numbers during spring at all stations, except for stations K2 (36 ind. $\mathrm{m}^{-3}$ within the subsurface layer) and $\mathrm{K} 3$ (49 ind. $\mathrm{m}^{-3}$ within the middle layer) (Fig. 14). These copepods became more abundant in summer, mainly in the middle layer at stations K0 (125 ind. $\mathrm{m}^{-3}$ ) and K2 (139 ind. $\mathrm{m}^{-3}$ ). The Microcalanus abundance increased further in the autumn, particularly at the glacial bay station $\mathrm{K} 5$, where it reached 563 and 290 ind. $\mathrm{m}^{-3}$ in the surface and subsurface layers, respectively. The abundance was also high in surface and subsurface layers at station K3 (166 ind. $\mathrm{m}^{-3}$ in each). Towards the open sea, Microcalanus was more numerous in the deeper parts of the water column. 

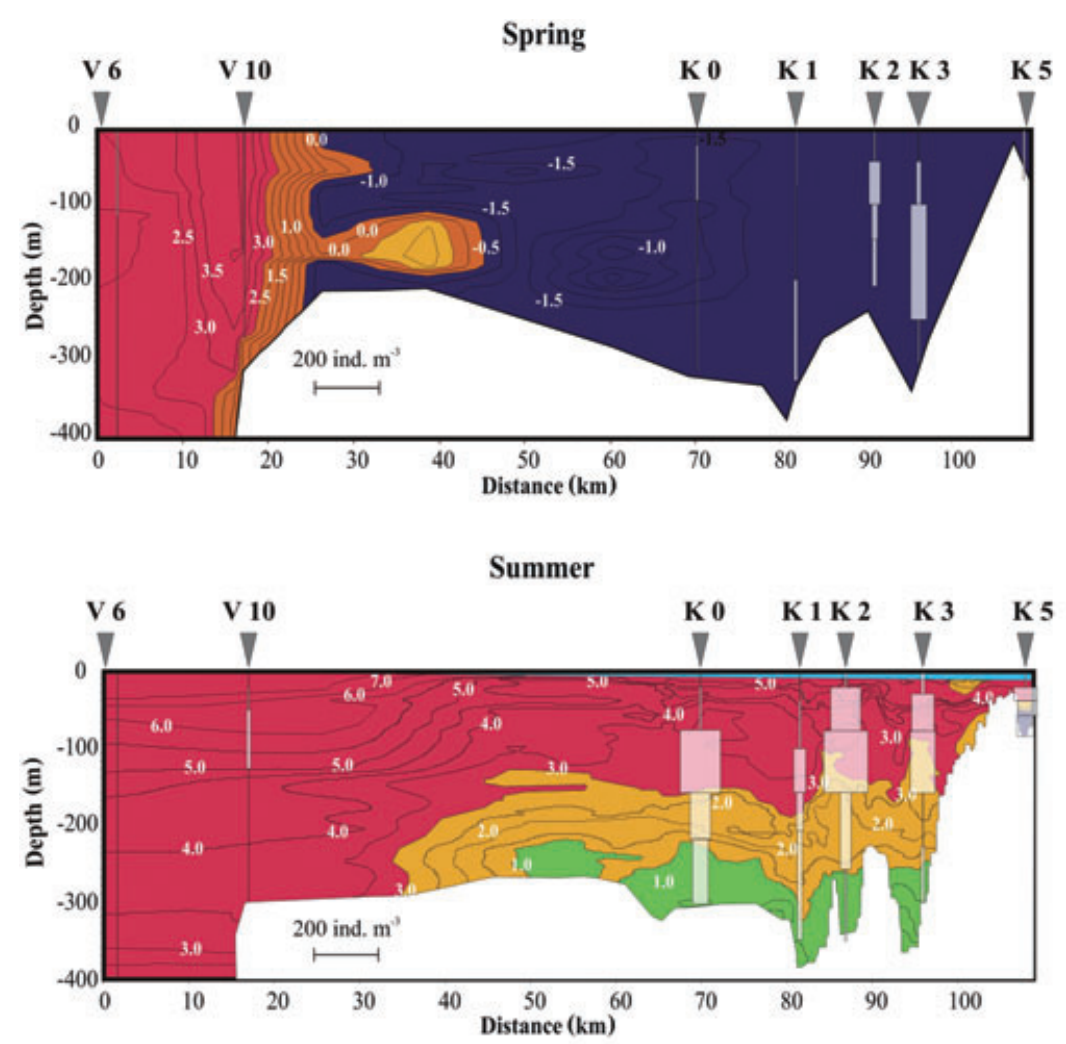

Fig. 14 Seasonal changes of Microcalanus spp. abundance (white rectangles; ind. $\mathrm{m}^{-3}$ ) along the transect running from the open sea into Kongsfjorden.

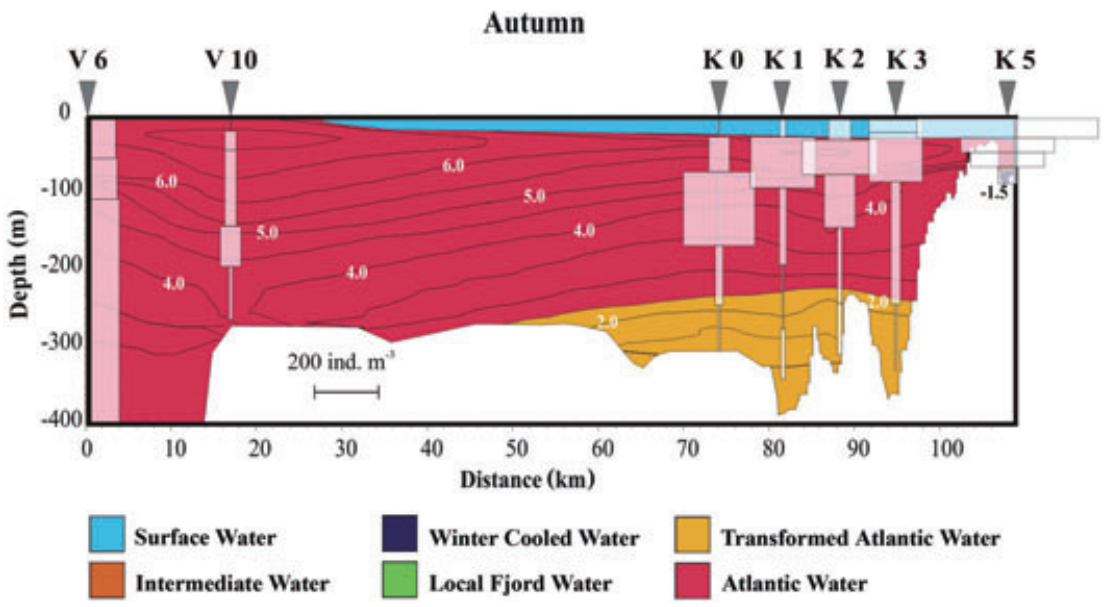

\section{Triconia borealis}

In spring, T. borealis was present in low numbers at all stations (maximum 3 ind. $\mathrm{m}^{-3}$ at station K5) (Fig. 15). In summer, its abundance increased both in the surface and bottom layers. The highest densities of this copepod in the bottom layer were recorded at stations $\mathrm{K} 0$ and $\mathrm{K} 2$ ( 371 and 560 ind. $\mathrm{m}^{-3}$, respectively), whereas the highest densities in the surface layers were at stations K2 and K5 (200 and 226 ind. $\mathrm{m}^{-3}$, respectively).
In autumn, T. borealis swarmed in the deeper layers, and reached 1240 ind. $\mathrm{m}^{-3}$ at station $\mathrm{K} 5$ and 391589 ind. $\mathrm{m}^{-3}$ at the other stations within the fjord.

\section{Cirripedia nauplii}

The naupliar stages of Cirripedia stay in the water column for a very short period before they become cyprids, and settle at the bottom. Mass appearances of this organism were recorded during the spring, although their distribu- 

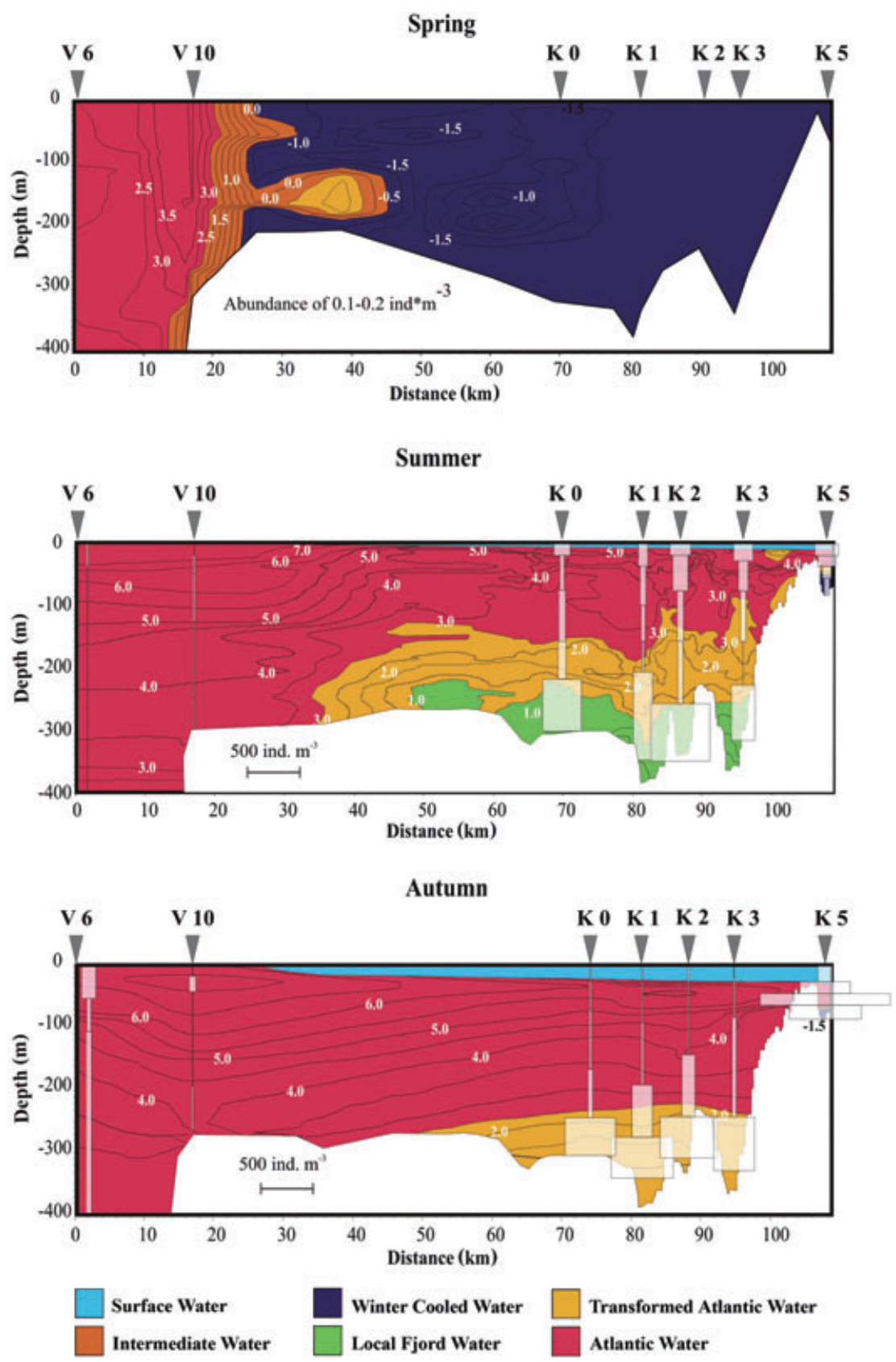

Fig. 15 Seasonal changes of Triconia borealis abundance (white rectangles; ind. $\mathrm{m}^{-3}$ ) along the transect running from the open sea into Kongsfjorden. Note that there is a different abundance scale for each season. tion was very patchy. Barnacle nauplii were particularly abundant at station $\mathrm{K} 0$ (456 ind. $\mathrm{m}^{-3}$, in the surface layer), and at nearby station $\mathrm{Kl}$ (3870 ind. $\mathrm{m}^{-3}$, in the middle layer). Such high densities were not found elsewhere, either in summer or in autumn.

\section{Echinodermata larvae}

The greatest abundance of Echinodermata larvae was recorded at the main fjord stations in summer. Their densities reached the highest values in the surface layer at stations $\mathrm{K} 3$ and $\mathrm{K} 2$, with 11670 and 10560 ind. $\mathrm{m}^{-3}$, respectively. Echinodermata larvae had a very patchy distribution, and did not play a role in other seasons.

\section{Statistical analysis}

Redundancy analysis (RDA) explained 38\% of the variance of the species-environment relationship in spring, but no significant correlation between the variability in 
Table 6 Marginal and conditional effects obtained from the forward selection of environmental variables. $\lambda_{1}$ is a fit with an eigenvalue based on a single variable only, whereas $\lambda_{\mathrm{A}}$ is an additional fit with an increase in the eigenvalue, $p$ is the significance level obtained with a Monte Carlo simulation using 499 unrestricted permutations.

\begin{tabular}{llll}
\hline Environmental variable & $\begin{array}{l}\text { Marginal } \\
\text { effects } \lambda_{1}\end{array}$ & $\begin{array}{l}\text { Conditional } \\
\text { effects } \lambda_{\mathrm{A}}\end{array}$ & p-value \\
\hline Spring & & & \\
Salinity & 0.21 & 0.21 & 0.006 \\
Depth layer & 0.20 & 0.13 & 0.020 \\
Temperature & 0.17 & 0.02 & 0.700 \\
Bottom depth & 0.05 & 0.02 & 0.624 \\
Summer & & & 0.002 \\
Depth layer & 0.43 & 0.43 & 0.002 \\
Salinity & 0.35 & 0.13 & 0.140 \\
Bottom depth & 0.17 & 0.06 & 0.002 \\
Temperature & 0.12 & 0.02 & 0.002 \\
Autumn & & & 0.002 \\
Salinity & 0.30 & 0.30 & 0.002 \\
Temperature & 0.16 & 0.16 & 0.424 \\
Depth layer & 0.20 & 0.06 & \\
Bottom depth & 0.07 & 0.02 & \\
\hline
\end{tabular}

zooplankton abundance and both the temperature and the depth at stations was found (Table 6, Fig. 16). There was, however, a statistically significant correlation between zooplankton and salinity, and also for particular depth layers. The first and second canonical axes explained 71 and $21 \%$ of the species-environment relationship, respectively. In spring, Eukrohnia hamata, M. longa, C. finmarchicus, Themisto abyssorum and Oikopleura were positively correlated with salinity, temperature and bottom depth. Ostracoda, Paraeuchaeta norvegica, Bradyidius similis and C. hyperboreus were positively correlated with a particular depth layer. Most of the taxa, however, were negatively correlated with all environmental variables.

The RDA analysis of summer zooplankton showed that $43 \%$ of zooplankton variability could be explained by variability in the depth layer (sampling depth), whereas $35 \%$ could be explained by salinity changes. All of the variables used in the model explained $65 \%$ of the observed zooplankton variability. Temperature also correlated significantly with zooplankton abundance. The first and second canonical axes explained 83 and $12 \%$ of the species-environment relationship, respectively. In summer, M. longa was positively correlated with a particular depth layer, whereas Ostracoda and E. hamata were positively correlated with salinity. Aglantha digitale, Oikopleura, Thysanoessa longicaudata and also C. finmarchicus were positively correlated with salinity.

The RDA of zooplankton collected in autumn revealed significantly positive correlations with temperature, salinity and depth layer, whereas the bottom depth correlation was not significant. The first and second canonical axes (a)

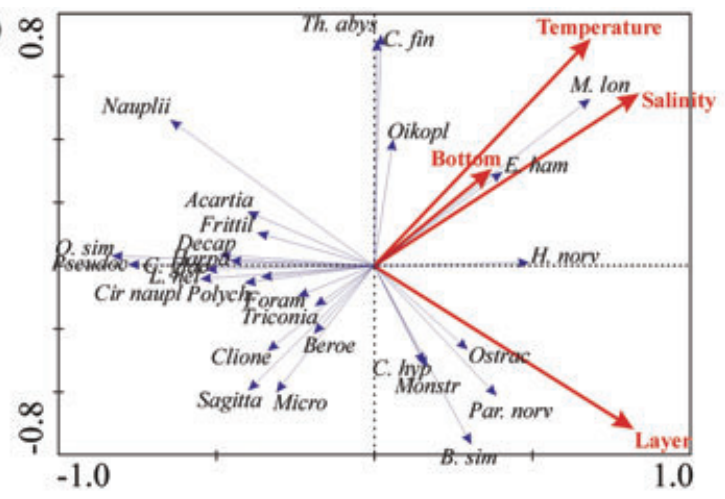

(b)

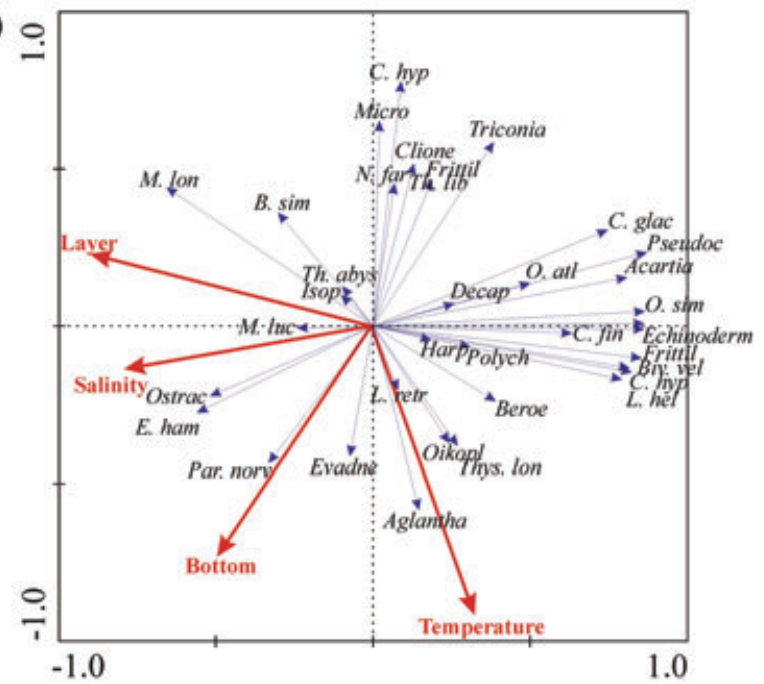

(c)

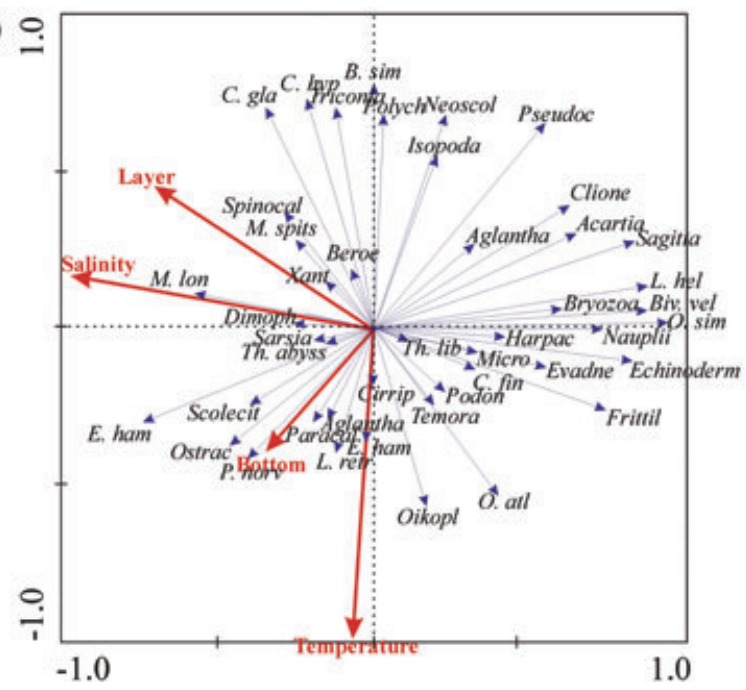

Fig. 16 Ordination diagrams based on redundancy analysis of $\log _{10^{-}}$ transformed zooplankton taxa densities in (a) spring, (b) summer and (c) autumn, with respect to environmental variables. Only species with $5 \%$ minimum fit to the lower axis are plotted. 
explained 61 and $31 \%$ of the species-environment relationship, respectively. Among many taxa positively correlated with depth layer were C. glacialis, C. hyperboreus and T. borealis, whereas C. finmarchicus, Oithona altantica and Oikopleura revealed a positive correlation with temperature. Ostracoda and P. norvegica were positively correlated with bottom depth, whereas T. borealis, C. glacialis and Pseudocalanus spp. were negatively correlated with temperature.

\section{Discussion}

\section{Oceanography}

In spring, the temperature and salinity distributions in the fjord were virtually homogeneous, and the entire fjord was filled with winter cooled water (WCW) (Svendsen et al. 2002; Cottier et al. 2005). The water column was weakly stratified over the shelf, and a distinct frontal zone formed over the shelf edge. The fjord waters were generally separated from the AW of the WSC, although some eastbound intrusions of AW across the front were noticeable.

During the summer, the oceanography of the fjord underwent rapid and considerable change. As a consequence of seasonal warming, the front weakened, and TAW penetrated into the fjord. Within the fjord, less saline and colder surface water (SW) was present, as a result of glaciers melting and land run-off (Cottier et al. 2005). This layer was the thickest in the glacial bay, and spread out onto the shelf nearly to station V10. In the deeper parts of the fjord, colder and more saline WCW was still present, as a remnant of the winter conditions. In addition, two other distinct water masses could be recognized in the fjord: intermediate water (IW) and local water (LW) (Cottier et al. 2005). All of the aforementioned water masses contributed to the greatly pronounced, but complicated, stratification of the water column in the fjord and over the shelf. The summer situation suggested an unobstructed exchange of water masses between the open sea, the shelf and the fjord itself, and hence the possibility of increased advection of zooplankton into the fjord. The general circulation pattern of Kongsfjorden assumes that water from the shelf enters the fjord along its southern coast, circulates inside the fjord, and flows out along the northern coast (Basedow et al. 2004; Cottier et al. 2005).

In autumn, the layer of SW was most likely thickened as a result of stronger glacier outflow, whereas the volume of cold water in the deeper part of the fjord decreased. The general stratification pattern observed in summer persisted, which suggested that the exchange of water masses between the fjord and the adjacent shelf was not limited by a hydrographic barrier, and showed that the zooplankton community in the fjord could be affected by advection of zooplankton into and out of the fjord.

Observations in Kongsfjorden in 2002, by means of sediment traps and CTD loggers on a single-point mooring in the outer part of the fjord, showed that the changes in water characteristics and associated zooplankton composition can be an abrupt process (Willis et al. 2006), but the dynamics of this process still needs to be investigated.

\section{Zooplankton}

The RDA analysis confirmed that there are three factors that play a significant role in the shaping of the zooplankton community: salinity and depth layer in spring, with temperature playing an additional role in summer and autumn. Piwosz et al. (2008) showed that the phytoplankton biomass and primary productivity decrease towards the inner fjord, as a result of light limitation (resulting from an increase in suspended sediments), which supports our understanding that the presence of a front has a substantial influence on the advection of zooplankton in Kongsfjorden.

The MDS and CLUSTER analyses revealed some differences between spring, summer and autumn in terms of zooplankton composition and abundance. The zooplankton community from the region studied underwent a change from low total abundance in spring to high densities in summer and autumn, similarly to the seasonal pattern in zooplankton abundance in other Arctic marine ecosystems (Hassel 1986; Weslawski et al. 1988; FalkPetersen et al. 1990; Weslawski, Jankowski et al. 1991). After a winter period of diapause, or reduced activity, the majority of zooplankters start to feed on the spring phytoplankton bloom, and commence reproduction.

The spring zooplankton grouping was characterized by a high proportion of $O$. similis, C. finmarchicus and Copepoda nauplii. Also, mass appearances of Cirripedia nauplii and other meroplanktonic larvae (mainly Polychaeta) were observed. The recorded densities of meroplankton were high compared with those previously found in other Arctic localities, e.g., in Hornsund (maximum 300 ind. $\mathrm{m}^{-3}$; Weslawski et al. 1988) or in the White Sea (maximum 728 ind. $\mathrm{m}^{-3}$; Oshurkov et al. 1982). Such high Cirripedia nauplii abundance in Kongsfjorden could be explained by the presence of large areas of hard bottom in the nearshore areas of the middle to outer fjord, particularly at the fjord entrance (Jørgensen \& Gulliksen 2001; Kaczmarek et al. 2005).

Oithona similis was the most numerous species throughout the study, and had the greatest impact on the 
zooplankton similarities among seasons and stations. Gallienne \& Robins (2001) considered $O$. similis to be the most abundant and ubiquitous species in the oceans of the world, whereas Fransz \& Gonzalez (1995) described $O$. similis as a eurythermal, euryhaline, omnivorous species, which is adapted to a wide range of habitats. Oithona similis was the most numerous zooplankton species in previous studies from the fjord and adjacent sea (e.g., Hop et al. 2002; Walkusz et al. 2003), as well as elsewhere in the Arctic (Pavshtiks 1980; Auel \& Hagen 2002; Blachowiak-Samolyk et al. 2006).

Calanus finmarchicus, which was also found in abundant quantities in the open sea/shelf and main fjord basin in summer, is an indicative species for Atlantic-derived waters (Hirche \& Mumm 1992; Kwasniewski et al. 2003). The WSC is regarded as the main transporting medium of this species from the Norwegian Sea to Svalbard waters (Aksnes \& Blindheim 1996; Scott et al. 2000; Hop et al. 2002; Karnovsky et al. 2003; Basedow et al. 2004). The densities of $C$. finmarchicus within the fjord during spring were relatively low in relation to summer and autumn, which suggests that the overwintering population in Kongsfjorden is supported by individuals from the WSC. The advection of water masses and zooplankton, which is limited during spring, possibly occurs later in the year, after the disappearance of the hydrographical barrier (Cottier et al. 2005; Willis et al. 2006). The number of adult females present during spring $\left(3\right.$ ind. $\mathrm{m}^{-3}$ ) would certainly not be sufficient for maintaining the local population.

Assuming that females spawn under ideal environmental conditions (i.e. with enough food being available and in an optimal temperature range) they would be able to lay as many as 1470 eggs $\mathrm{m}^{-3}$ (24.5 eggs female ${ }^{-1}$ day $^{-1}$, and spawning extends for 20 days; Niehoff et al. 1999). Hirche (1990), however, suggested that an individual female might only lay a total of 200 eggs in cold Arctic water (600 eggs $\mathrm{m}^{-3}$ in our case). If we consider natural mortality (either resulting from physiological processes or environmental variability) and predation risk, which together may account for a loss of up to $2.4 \%$ per day (Bagøien et al. 2001), a low number of individuals would survive from April to July. If we also take into consideration that $C$. finmarchicus develops into older stages more slowly at low temperatures (Hansen et al. 2003), it seems unlikely that a local population could be maintained without advection of individuals.

During summer and autumn, the highest total zooplankton abundance was in the inner glacial bay (in the summer/autumn inner-basin grouping), which differed from the situation in previous years, when a higher zooplankton abundance was found in the central part of the fjord (Hop et al. 2002). We think that such a situation is the result of strong and unrestrained advection from the shelf into the main fjord, and then further past the sill into the relatively shallow ( $>90 \mathrm{~m}$ ) inner bay. Zooplankton probably becomes entrapped in the inner bay as a result of the circulation pattern, and because of unfavourable water conditions in both the bottom layer (WCW) and surface layer, where fresh water from glacier and river run-off prevails (Weslawski et al. 2000; Cottier et al. 2005). However, these harsh conditions do not seem to be a problem for taxa that are adapted to low salinity (e.g., O. similis) or low temperature (e.g., Pseudocalanus spp.).

The seasonal variability of $O$. similis abundance, with low densities in spring, and a gradual increase in summer and autumn, has been previously reported in Kongsfjorden (Lischka \& Hagen 2005). This is most likely to result from an extended spawning season (Ashjian et al. 2003), with peaks during May-September (Lischka \& Hagen 2005). Our data from spring was from April, well in advance of the reproductive period. Spring reproduction resulted in an enhanced abundance during summer, whereas the highest abundance of $O$. similis in autumn was the result of a second mass spawning. Characteristic conditions such as the co-occurrence of different water masses with the presence of steep environmental gradients, and the local circulation pattern, make Kongsfjorden a favourable ecosystem for $O$. similis. The abundances of $O$. similis observed in our study were in the same range as those reported by Lischka \& Hagen (2005), although our sampling net $(0.180-\mathrm{mm}$ mesh) was coarser than Lischka \& Hagen's (0.100-mm mesh), and hence we may have missed some of the population. Thus, it seems justified to assume that there were more O. similis in 2002 compared with previous studies, although we cannot back-calculate the total abundance because of this lack of the smallest fraction.

The densities of Pseudocalanus spp. recorded in our study exceeded those found in Kongsfjorden by Lischka \& Hagen (2005), and we think that two reasons for this should be considered. The first explanation could be that the interannual variability and increasing abundance of small taxa (O. similis and Pseudocalanus spp.) observed in Kongsfjorden, between 1996 and 2002, result from an intensified Atlantic influence on the system (Hop at al. 2006; Willis et al. 2006). The second explanation is that zooplankton advected into the relatively shallow basin of the glacial bay become entrapped, and glacial run-off limits the feeding habitat (Weslawski et al. 2000). Our finding of a higher abundance of Pseudocalanus spp. in autumn agrees with the results of earlier studies from this region, which describe autumn as the period when the representatives of this genus attain their peak abundances in relation to life cycle dynamics (e.g., Lischka $\&$ Hagen, 2005). 
Another taxon that was abundant in the glacial bay in summer and autumn was Microcalanus spp., which consists of two species: M. pygmaeus and M. pusillus (Walkusz et al. 2003). These two species were treated together in this study. The taxonomy of this genus is still a matter of debate, and sampling was performed with a mesh that was too coarse to accurately sample the developmental stages of both species. Recent studies suggest that $M$. pygmaeus is most often found in samples from high latitudes (Weslawski, Kwasniewski et al. 1991; Mumm 1993; Kosobokova et al. 1998; Kosobokova \& Hirche 2000; Auel \& Hagen 2002; Ashjian et al. 2003), whereas $M$. pusillus is recorded in more Boreal localities (Barthel et al. 1995), and was considered by Østvedt (1955) and Wiborg (1955) to be characteristic of the Atlantic fauna.

Microcalanus spp. undergo seasonal migrations to greater depths during the early summer (Head et al. 2003). In Kongsfjorden and the adjacent shelf, Microcalanus spp. avoided the surface and subsurface layers during spring and summer, and were instead found in the deeper parts of the water column, in agreement with the results of previous observations from the Norwegian Sea (Østvedt 1955; Wiborg 1955). Other studies have shown that Microcalanus spp. are generally limited to the upper $50 \mathrm{~m}$ of the water column (Kosobokova 1980; Grainger 1989; Kosobokova \& Hirche 2000; Ashijan et al. 2003). Such a situation occurred in Kongsfjorden during autumn, when Microcalanus spp. were concentrated in the upper water layers close to the glaciers. This could result from a preference of this species for colder water (Head et al. 2003). In the layer where Microcalanus was abundant, the temperature ranged between 3.0 and $4.0^{\circ} \mathrm{C}$, whereas it was higher $\left(5.5-6.0^{\circ} \mathrm{C}\right)$ in the water layers below. Another factor that should be responsible for high abundances in the inner bay is the mechanical concentration of plankton by circulating currents, a phenomenon that has been reported previously in Kongsfjorden (Weslawski et al. 2000; Zajaczkowski \& Legezynska 2001).

The zooplankton observed in the main fjord in summer (summer fjord grouping) and autumn (autumn fjord grouping) were the most similar, characterized not only by a high abundance of $O$. similis, but also by the major contributions of C. finmarchicus, Pseudocalanus spp. and T. borealis. Echinodermata larvae played an important role during the summer.

The distribution of $C$. finmarchicus in the fjord is influenced by several biological and physical factors. It has been shown, for example, that Calanus species form stagespecific aggregations (Kwasniewski et al. 2003). Because of their different depth distributions and separate circulation patterns at different depths, individuals can be transported within the fjord along different pathways (Basedow et al. 2004). The high abundance of $C$. finmarchicus towards the end of the main basin (particularly at station K3) in summer could result from an eddy formation, as has been determined from models (Ingvaldsen et al. 2001). The aggregation of the species in the surface layers was also observed by Basedow et al. (2004). The decreasing abundance of $C$. finmarchicus towards autumn could be the effect of population mortality, but could also partly result from unbalanced advection (with a prevailing outflow over the inflow). In autumn, when there was stronger freshwater run-off, the inflow into the fjord most likely took place within subsurface layers, which are void of $C$. finmarchicus individuals, whereas the outflow was in surface layers still occupied by some of the population. There were also differences in population stage composition between the shelf and fjord stations, and the population in the fjord was usually delayed compared with the WSC population. Because C. finmarchicus is a Boreal species, we postulate that the delayed seasonal increase of temperature, and the generally lower temperature, resulting from the local cooling in the fjord, could be responsible for the differences in population demography. In addition, different food quality outside its original habitat (WSC) or competition from sibling species could play a role.

It has been found that T. (= Oncaea) borealis prefers greater depths in the Norwegian Sea (Østvedt 1955), as well as in the Arctic Ocean (Auel \& Hagen 2002). The species was only observed at shallower levels in the water column in May and June, at the beginning of a period of increased abundance that lasted throughout the second part of the year (Østvedt 1955).

We postulate that the seasonal changes in the abundance of $T$. borealis in Kongsfjorden (i.e., very low abundance in spring, and increased abundance during summer and autumn) generally mimics the seasonal abundance pattern described for the Norwegian Sea. As an open-sea/deep-water species, T. borealis is most likely to be an expatriate in Kongsfjorden, and its abundance will largely depend on advection. The source of $T$. borealis for Kongsfjorden is presumably the WSC, which has also been found to be the main source of the species in the nearby area of the Nansen Basin, Arctic Ocean (Auel \& Hagen 2002). Because no advection took place in Kongsfjorden prior to summer in 2002 (Cottier et al. 2005; this study), the stock of $T$. borealis remained at a low level of abundance.

The zooplankton species of the open sea and the shelf were clustered together, with high percentages of $O$. similis, C. finmarchicus and Pseudocalanus spp., as well as of $M$. longa. The seasonality in the abundance of $M$. longa confirmed observations in studies from the Arctic Ocean 
(Minoda 1967), Baffin Bay (North Water Polynya; Ringuette et al. 2002) and Norwegian fjords (Grønvik \& Hopkins 1984). In our study, $M$. longa was abundant in the deeper parts of the water column, which is consistent with previous observations in Kongsfjorden (Hop et al. 2002), Hornsund (Walkusz 2006) and the Barents Sea (Blachowiak-Samolyk et al. 2006). In our study, this is also confirmed by a positive correlation between the abundance of $M$. longa and its occurrence in a particular water depth layer. As it is considered to be an Arctic species (Beaugrand et al. 2002), its migration to greater depths, in our case, is likely to be a strategy to avoid the relatively warm TAW. The presence of $M$. longa in deeper parts of the water column could also be related to depth segregation, which reduces competition (Geynrikh et al. 1983; Falkenhaug et al. 1997; Kosobokova et al. 1998; Mumm et al. 1998), as well as predation by pelagic predators such as polar cod (Boreogadus saida) (Joensen 2008). The age structure observed during this survey was typical for M. longa, with mature individuals prevailing during spring (Geynrikh et al. 1983), younger stages (CI-CIII) being abundant in summer and older stages being abundant in autumn (Minoda 1967).

Another species that occurred in summer in high abundance on the shelf was the Arctic $C$. glacialis. The source area for the Arctic water masses is the northern Barents Sea, and the water masses are transported from there to the shelf off western Spitsbergen via Storfjorden, first as the Sørkapp Current, and later as the northward flowing coastal current (Cottier et al. 2006). Little information is available on the possible influence of this coastal current on the oceanography of the west Spitsbergen coast (Saloranta \& Svendsen 2001), but it has been shown to be important for marine biota in this region, particularly the little auk (Alle alle) (Karnovsky et al. 2003).

Similarly to the other zooplankters, C. glacialis had a low abundance in spring, and a much higher abundance in summer and autumn. Usually, the highest abundance of this species was found within Kongsfjorden, whereas the abundances were much lower on the shelf and at the station in the WSC, similar to earlier observations (Basedow et al. 2004). An exception was the high abundance recorded during summer in the surface layers at the shelf station V10. This station was in an area potentially influenced by the coastal current, although the water masses in the vicinity of V10 did not show signatures of the Arctic or shelf waters in our study. The Arctic water mass in this part of the coastal current probably loses its signature because of solar radiation or heat exchange with the atmosphere, and because of mixing with adjacent water masses from fjords and the WSC. Arctic water from the Barents Sea is probably present on the shelf as intrusions rather than continuous layers, especially at a distance from the source region (Saloranta \& Svendsen 2001).

The oceanography and bathymetry on the shelf west of Spitsbergen acts in favour of cross-front exchange towards the coast (i.e., the transport of Atlantic water onto the shelf), but reversed exchange (the transport of Arctic or shelf water offshore) is also possible (Saloranta \& Svendsen 2001), thereby creating mechanisms for advection of zooplankton from fjords and coastal waters offshore. The high abundance of C. glacialis at station V10 resulted from a high number of younger copepodid stages, particularly stage I. In Arctic waters, C. glacialis typically has a two-year life cycle (Tande et al. 1985; Scott et al. 2000): it is usually represented in a particular location and time by two generations (Kosobokova et al. 1998; Arashkievich et al. 2002; Kwasniewski et al. 2003; Thor et al. 2005). However, a mixed one-/two-year cycle (Slagstad \& Tande 1990; Arnkvaern et al. 2005), or even a yearly cycle (Smith 1990; Scott et al. 2000), have been reported. Earlier observations from Spitsbergen in July showed that the generation of that year had already developed to CII and CIII (Kwasniewski et al. 2003). Arashkievich et al. (2002) reported the presence of CI of C. glacialis in the northern Barents Sea in July, and this stage also peaked in western Greenland (Disko Bay) in July (Madsen et al. 2001). Late reproduction has also been reported from eastern Canadian waters (Grainger 1963). The likely explanation for the observed situation is that reproduction was delayed in the year of our study, and that the CI specimens, which were predominant at station V10, as well as at some stations in Kongsfjorden, were the offspring of late-spawning females.

The distribution of C. glacialis inside Kongsfjorden was more typical, and can be understood in the context of the species biology and interaction with the oceanographic conditions. As an Arctic shelf species, C. glacialis tends to avoid warmer waters, and does not usually tolerate the temperatures found near the surface in late summer and autumn (Kosobokova 1999), especially at the older copepodid stages IV-VI. Younger stages might be more resistant to higher temperatures (and lower salinities), and may also benefit from better feeding conditions in the surface waters (Madsen et al. 2001; Kwasniewski et al. 2003). This might explain their presence in the surface layers, and the positive correlation between the abundance of $C$. glacialis and temperature revealed by RDA. Young stages are also less likely to be vulnerable to visual predators because of their smaller size and lesser pigmentation (Hays et al. 2001). The concentration of older stages in deeper waters during summer and autumn may be explained by their preference for lower temperatures, and their life cycle, which includes a descent to bottom layers for overwintering. 
Some of the zooplankton taxa collected in this study had not been recorded previously in the Svalbard fjords (Stott 1936; Digby 1961; Koszteyn \& Kwasniewski 1989; Kwasniewski 1990; Hop et al. 2002; Kwasniewski et al. 2003; Walkusz et al. 2003; Walkusz et al. 2004; Hop et al. 2006). Our study included sampling outside of the fjord, where the zooplankton community over the shelf is supplemented with deepwater species such as Aetideopsis rostrata, or species of the genus Spinocalanus (Østvedt 1955; Richter 1994; Hop et al. 2006). Anomalocera patersoni and P. parvus prefer warm water, and have been recorded at station $M$ in the Norwegian Sea (Østvedt 1955). Aetideus armatus and S. lamellatus belong to hyperbenthic copepods (Boxshall \& Halsey 2004), and are known from bottom layers in Norwegian fjords (Sars 1902). The presence of new taxa in our samples could also be the result of more intensive Atlantic influx, which greatly influenced the waters of Svalbard in 2002 (Berge et al. 2005).

\section{Conclusions}

Seasonal observations of ecosystem dynamics in Kongsfjorden revealed that a strong front was observed in spring between the open sea and the fjord waters: it effectively prevented water mass exchange. This front dissolved before the summer, and advection of Atlantic water became a dominating factor in the shaping of the zooplankton community. Zooplankton, in general, followed water mass dynamics, with distinct differences from spring to autumn. The total zooplankton abundance during spring was much lower than in summer and autumn. In spring, the higher densities of zooplankton were observed in the outer part of the fjord, whereas later in the course of the year the total zooplankton abundance was highest in the glacial bay. Abundances of particular zooplankton taxa were also much higher in summer and autumn compared with spring. Small zooplankters (O. similis, Pseudocalanus spp., T. borealis) displayed the most pronounced density increase from spring to autumn, particularly at the inner part of the fjord, most likely as a result of the local circulation pattern within the fjord.

A few taxa ( $S$. lamellatus, A. rostrata, A. armatus, A. patersoni, S. abyssalis and $P$. parvus) were recorded in Svalbard waters for the first time, but we think this was because of either more extensive sampling conducted throughout 2002 or more extensive Atlantic influx in that particular year.

We found that the following factors played an important role in shaping the zooplankton community: the presence of a local front, advection, the circulation pattern observed in the fjord and bottom topography.

\section{Acknowledgements}

We thank the crews of the research vessels Lance, Oceania and Jan Mayen for their assistance during sampling. This project was partly supported by the Polish State Committee for Scientific Research (grant 2 P04F 049 26).

\section{References}

Aksnes D.L. \& Blindheim J. 1996. Circulation patterns in the north Atlantic and possible impact on population dynamics of Calanus finmarchicus. Ophelia 44, 7-28.

Arashkievich E., Wassmann P., Pasternak A. \& Wexels Riser C. 2002. Seasonal and spatial changes in biomass, structure, and development progress of the zooplankton community in the Barents Sea. Journal of Marine Systems 38, 125-145.

Arnkvaern G., Daase M. \& Eiane K. 2005. Dynamics of coexisting Calanus finmarchicus, Calanus glacialis and Calanus hyperboreus populations in a high-Arctic fjord. Polar Biology 28, 528-538.

Ashjian C.J., Campbell R.G., Welch H.E., Butler M. \& van Keuren D. 2003. Annual cycle in abundance, distribution, and size in relation to hydrography of important copepod species in the western Arctic Ocean. Deep-Sea Research Part I 50, 1235-1261.

Astthorsson O.S. \& Gislason A. 2003. Seasonal variations in abundance, development and vertical distribution of Calanus finmarchicus, C. hyperboreus and C. glacialis in the East Icelandic Current. Journal of Plankton Research 25, 843-854.

Auel H. \& Hagen W. 2002. Mesozooplankton community structure, abundance and biomass in the central Arctic Ocean. Marine Biology 140, 1013-1021.

Bagøien E., Kaartvedt S., Asknes D.L. \& Eiane K. 2001. Vertical distribution and mortality of overwintering Calanus. Limnology and Oceanography 46, 1494-1510.

Barthel K.-G., Noji T.T. \& Noji C.I.-M. 1995. Zooplankton dynamics during the onset of winter in a northern Norwegian fjord. Vertical distribution and metabolic activity in relation to phytoplankton and sedimentation. Sarsia 80, 23-32.

Basedow S., Eiane K., Tverberg V. \& Spindler M. 2004. Advection of zooplankton in an Arctic fjord (Kongsfjorden, Svalbard). Estuarine, Coastal and Shelf Science 60, 113-124.

Beaugrand G., Ibanez F., Lindley A.J. \& Reid P.C. 2002. Diversity of calanoid copepods in the North Atlantic and adjacent seas: species associations and biogeography. Marine Ecology Progress Series 232, 179-195.

Berge J., Johnsen G., Nilsen F., Gulliksen B. \& Slagstad D. 2005. Ocean temperature oscillations enable reappearance of blue mussels Mytilus edulis in Svalbard after a 1000 year absence. Marine Ecology Progress Series 303, 167-175.

Blachowiak-Samolyk K., Kwasniewski S., Richardson K., Dmoch K., Hansen E., Hop H., Falk-Petersen S. \& Mouritsen L.T. 2006. Arctic zooplankton do not perform diel vertical migration (DVM) during periods of midnight sun. Marine Ecology Progress Series 308, 101-116. 
Boxshall G.A. \& Halsey H.A. (eds.) 2004. An introduction to copepod diversity. London: Ray Society.

Clarke K.R. \& Warwick R.M. 1994. Change in marine communities: an approach to statistical analysis an interpretation. Plymouth: Plymouth Marine Laboratory.

Cooney R.T., Coyle K.O., Stockmar E. \& Stark C. 2001. Seasonality in surface-layer net zooplankton communities in Prince William Sound, Alaska. Fisheries Oceanography 10, 97-109.

Cottier F.R., Tarling G.A., Wold A. \& Falk-Petersen S. 2006. Unsynchronised and synchronised vertical migration of zooplankton in a High Arctic fjord. Limnology and Oceanography 51, 2586-2599.

Cottier F., Tverberg V., Inall M., Svendsen H., Nilsen F. \& Griffiths C. 2005. Water mass modification in an Arctic fjord through cross-shelf exchange: the seasonal hydrography of Kongsfjorden, Svalbard. Journal of Geophysical Research 110, C12005, doi: 10.1029/ 2004JC002757.

Digby P.S.B. 1961. The vertical distribution and movements of marine plankton under midnight-sun conditions in Spitsbergen. Journal of Animal Ecology 30, 9-25.

Falkenhaug T., Tande K.S. \& Semenova T. 1997. Diel, seasonal and ontogenic variations in the distribution of four marine copepods. Marine Ecology Progress Series 149, 105-119.

Falk-Petersen S., Hopkins C.C.E. \& Sargent J.R. 1990. Trophic relationships in the pelagic, Arctic food web. In M. Barnes \& R.N. Gibson (eds.): Trophic relationships in the marine environment. Proceedings of 24th European Marine Biology Symposium. Pp. 315-333. Aberdeen: Aberdeen University Press.

Falk-Petersen S., Hagen W., Kattner W., Clarke A. \& Sargent J. 2000. Lipids, trophic relationships, and biodiversity in Arctic and Antarctic krill. Canadian Journal of Fisheries and Aquatic Sciences 57, 178-191.

Field J.G., Clarke K.R. \& Warwick R.M. 1982. A practical strategy for analyzing multispecies distribution patterns. Marine Ecology Progress Series 8, 37-52.

Fleming K.M., Dowdeswell J.A. \& Oerlemans J. 1997. Modelling the mass balance of northwest Spitsbergen glaciers and responses to climate change. Annals of Glaciology 24, 203-210.

Fransz H.G. \& Gonzalez S.R. 1995. The production of Oithona similis (Copepoda: Cyclopoida) in the Southern Ocean. ICES Journal of Marine Science 52, 549-555.

Gallienne C.P. \& Robins D.B. 2001. Is Oithona the most important copepod in the world's oceans? Journal of Plankton Research 23, 1421-1432.

Geynrikh A.K., Kosobokova K.N. \& Rudyakov Yu.A. 1983. Seasonal variations in the vertical distribution of some prolific copepods of the Arctic Basin. Canadian Translations of Fisheries and Aquatic Sciences 4925. Ottawa: Fisheries Research Board of Canada.

Grainger E.H. 1963. Copepods of the genus Calanus as indicators of Eastern Canadian Waters. In M.J. Dunbar (ed.): Marine distributions. Pp. 68-94. Toronto: University of Toronto Press.
Grainger E.H. 1989. Vertical distribution of zooplankton in the central Arctic Ocean. In L. Rey \& V. Alexander (eds.): Proceedings of the sixth conference of the Comite Arctique International, 13-15 May 1985. Pp. 48-60. Leiden: E.J. Brill.

Grønvik S. \& Hopkins C.C.E. 1984. Ecological investigations of the zooplankton community of Balsfjorden, northern Norway: generation cycle, seasonal vertical distribution, and seasonal variations in body weight and carbon and nitrogen content of the copepod Metridia longa (Lubbock). Journal of Experimental Marine Biology and Ecology 80, 93-107.

Hansen B.W., Marker T., Andreassen P., Arashkevich E., Carlotti F., Lindeque P., Tande K.S. \& Wagner M. 2003. Differences in life-cycle traits of Calanus finmarchicus originating from $60^{\circ} \mathrm{N}$ and $69^{\circ} \mathrm{N}$, when reared in mesocosms at $69^{\circ} \mathrm{N}$. Marine Biology 142, 877-893.

Hassel A. 1986. Seasonal changes in zooplankton composition in the Barents Sea, with special attention to Calanus spp. (Copepoda). Journal of Plankton Research 8 , 329-339.

Hays G.C., Kennedy H. \& Frost B.W. 2001. Individual variability in diel vertical migration of a marine copepod: why some individuals remain at depth when others migrate. Limnology and Oceanography 46, 2050-2054.

Head E.J.H., Harris L.R. \& Yashayew I. 2003. Distribution of Calanus spp. and other mesozooplankton in the Labrador Sea in relation to hydrography in spring and summer (1995-2000). Progress in Oceanography 59, 1-30.

Hirche H.-J. 1990. Egg production of Calanus finmarchicus at low temperature. Marine Biology 106, 53-58.

Hirche H.-J. \& Mumm N. 1992. Distribution of dominant copepods in the Nansen Basin, Arctic Ocean, in summer. Deep-Sea Research Part I 39, 485-505.

Hop H., Falk-Petersen S., Svendsen H., Kwasniewski S., Pavlov V., Pavlova O. \& Søreide J.E. 2006. Physical and biological characteristics of the pelagic system across Fram Strait to Kongsfjorden. Progress in Oceanography 71, 182-231.

Hop H., Pearson T., Hegseth E.N., Kovacs K.M., Wiencke C., Kwasniewski S., Eiane K., Mehlum F., Gulliksen B., Wlodarska-Kowalczuk M., Lydersen C., Weslawski J.M., Cochrane S., Gabrielsen G.W., Leakey R.J.G., Lønne O.J., Zajaczkowski M., Falk-Petersen S., Kendall M., Wängberg S.-Å., Bischof K., Voronkov A.Y., Kovaltchouk N.A., Wiktor J., Poltermann M., di Prisco G., Papucci C. \& Gerland S. 2002. The marine ecosystem of Kongsfjorden, Svalbard. Polar Research 21, 167-208.

Ingvaldsen R., Reitan M.B., Svendsen H. \& Asplin L. 2001. The upper layer circulation in Kongsfjorden and Krossfjorden-a complex fjord system on the west coast of Spitsbergen. Memoirs of National Institute of Polar Research, Special Issue 54, 393-407.

Joensen J. 2008. Comparative feeding ecology of the sympatric cod fishes Arctogadus glacialis and Boreogadus saida in north-east Greenland evaluated from diet and stable isotope analyses. Master's thesis, University of Tromsø. 
Jørgensen L.L. \& Gulliksen B. 2001. Rocky bottom fauna in Arctic Kongsfjord (Svalbard) studied by means of suction sampling and photography. Polar Biology 24, 113-121.

Kaczmarek H., Wlodarska-Kowalczuk M., Legezynska J. \& Zajaczkowski M. 2005. Shallow sublitoral macrozoobenthos in Kongsfjorden, west Spitsbergen, Svalbard. Polish Polar Research 26, 137-155.

Karnovsky N., Kwasniewski S., Weslawski J.M., Walkusz W. \& Beszczynska-Møller A. 2003. The foraging behaviour of little auks in a heterogeneous environment. Marine Ecology Progress Series 253, 289-303.

Kosobokova K.N. 1980. Sezonnye izmeneniya vertikaln'nogo raspredeleniya i vozrastnogo sostava populatsij Microcalanus pygmaeus, Oithona similis, Oncea borealis i O. notopus v tsentral'nom Arkticheskom bassejna. (Seasonal variations in the vertical distribution and age composition of Microcalanus pygmaeus, Oithona similis, Oncaea borealis and O. notopus populations in the central Arctic basin.) In M.E. Vinogradov \& I.A. Mel'nikov (eds.): Biologiya Tsentral'nogo Arkicheskogo Basseyna. (Biology of the central Arctic Basin.) Pp. 167-182. Moscow: Nauka.

Kosobokova K.N. 1999. The reproductive cycle and life history of the Arctic copepod Calanus glacialis in the White Sea. Polar Biology 22, 254-263.

Kosobokova K.N., Hanssen H., Hirche H.-J. \& Knickmeier K. 1998. Composition and distribution of zooplankton in the Laptev Sea and adjacent Nansen Basin during summer, 1993. Polar Biology 19, 63-76.

Kosobokova K. \& Hirche H.-J. 2000. Zooplankton distribution across the Lomonosov Ridge, Arctic Ocean: species inventory, biomass and vertical structure. Deep-Sea Research Part I 47, 2029-2060.

Koszteyn J. \& Kwasniewski S. 1989. Comparison of fjord and shelf mesozooplankton communities of the southern Spitsbergen region. Rapports et Procès-Verbaux des Réunions du Conseil International pour l'Exploration de la Mer 188, 164-169.

Kwasniewski S. 1990. A note of zooplankton of the Hornsund Fjord and its seasonal changes. Zeszyty Naukowe Wydzialu BgiO UG 12, 7-27.

Kwasniewski S., Hop H., Falk-Petersen S. \& Pedersen G. 2003. Distribution of Calanus species in Kongsfjorden, a glacial fjord in Svalbard. Journal of Plankton Research 25, $1-20$.

Lischka S. \& Hagen W. 2005. Life histories of the copepods Pseudocalanus minutus, P. acuspes (Calanoida) and Oithona similis (Cyclopoida) in the Arctic Kongsfjorden (Svalbard). Polar Biology 28, 910-921.

Madsen S.D., Nielsen T.G. \& Hansen B.W. 2001. Annual population development and production by Calanus finmarchicus, C. glacialis and C. hyperboreus in Disko Bay, western Greenland. Marine Biology 139, 75-93.

Melnikov I.A. 2000. The Arctic sea ice ecosystem and global warming. In H. P. Huntington (ed.): Impacts of changes in sea ice and other environmental parameters in the Arctic: final report of the Marine Mammal Commission Workshop, Girdwood,
Alaska, 15-17 February 2000. Bethesda, MD: Marine Mammal Commission.

Minoda T. 1967. Seasonal distribution of Copepoda in the Arctic Ocean from June to December, 1964. Recent Oceanic Works in Japan 9, 161-168.

Mumm N. 1993. Composition and distribution of mesozooplankton in the Nansen Basin, Arctic Ocean, during summer. Polar Biology 13, 541-461.

Mumm N., Auel H., Hanssen H., Hagen W., Richter C. \& Hirche H.-J. 1998. Breaking the ice: large-scale distribution of mesozooplankton after a decade of Arctic and transpolar cruises. Polar Biology 20, 189-197.

Niehoff B., Klenke U., Hirche H.-J., Irigoien X., Head R. \& Harris R. 1999. A high frequency time series at Weathership M, Norwegian Sea, during the 1997 spring bloom: the reproductive biology of Calanus finmarchicus. Marine Ecology Progress Series 176, 81-92.

Oshurkov V.V., Shilin M.B., Oksov I.V. \& Smirnov B.R. 1982. Seasonal dynamics of meroplankton in Chupa Inlet (White Sea). Soviet Journal of Marine Biology 8, 1-8.

Østvedt O.J. 1955. Zooplankton investigations from Weather Ship $M$ in the Norwegian Sea, 1948-49. Hvalrådets Skrifter 40. Oslo: Norwegian Academy of Science.

Pavshtiks E.A. 1980. Some patterns in the life of the plankton of the central Arctic Basin. Canadian Translations of Fisheries and Aquatic Sciences 4917. Ottawa: Fisheries Research Board of Canada.

Piwosz K., Walkusz W., Hapter R., Wieczorek P., Hop H. \& Wiktor J. 2008. Comparison of productivity and phytoplankton in a warm (Kongsfjorden) and a cold (Hornsund) Spitsbergen fjord in mid-summer 2002. Polar Biology, doi: 10.1007/s00300-008-0549-2.

Richter C. 1994. Regional and seasonal variability in the vertical distribution of mesozooplankton in the Greenland Sea. Reports on Polar Research 154. Kiel: University of Kiel.

Richter C. 1995. Seasonal changes in the vertical distribution of mesozooplankton in the Greenland Sea Gyre $\left(75^{\circ} \mathrm{C}\right)$ : distribution strategies of calanoid copepods. ICES Journal of Marine Science 52, 533-539.

Ringuette M., Fortier L., Fortier M., Runge J.A., Belanger S., Larouche P., Weslawski J.M. \& Kwasniewski S. 2002. Advanced recruitment and accelerated population development in Arctic calanoid copepods of the North Water. Deep-Sea Research Part II 49, 5081-5099.

Saloranta T.M. \& Svendsen H. 2001. Across the Arctic Front west of Spitsbergen: high-resolution CTD sections from 1998-2000. Polar Research 20, 177-184.

Sars G.O. 1902. An account of the Crustacea of Norway. 4. Copepoda, Calanoida. Parts 3-12. Bergen: Bergen Museum.

Slagstad D., Tande K. 1990. Growth and production dynamics of Calanus glacialis in an Arctic pelagic food web. Marine Ecology Progress Series 63, 189-199.

Scott C.L., Kwasniewski S., Falk-Petersen S. \& Sargent J.R. 2000. Lipids and life strategies of Calanus finmarchicus, Calanus glacialis and Calanus hyperboreus in late autumn, Kongsfjorden, Svalbard. Polar Biology 23, 510-516. 
Smith S.L. 1990. Egg production and feeding by copepods prior to the spring bloom of phytoplankton in Fram Strait, Greenland Sea. Marine Biology 106, 59-69.

Stempniewicz L., Blachowiak-Samolyk K. \& Weslawski J.M. 2007. Impact of climate change on zooplankton communities, seabird populations and Arctic ecosystem-a scenario. Deep-Sea Research Part II 54, 2934-2945.

Stott F.C. 1936. The marine foods of birds in an inland fjord region in west Spitsbergen. Journal of Animal Ecology 5, 356-369.

Svendsen H., Beszczynska-Møller A., Hagen J.O., Lefauconnier B., Tverberg V., Gerland S., Ørbæk J.B., Bischof K., Papucci C., Zajaczkowski M., Azzolini R., Bruland O., Wiencke C., Winther J.-G. \& Dallmann W. 2002. The physical environment of Kongsfjorden-Krossfjorden, an Arctic fjord system in Svalbard. Polar Research 21, 133-166.

Tande K.S., Hassel A. \& Slagstad D. 1985. Gonad maturation and possible life cycle strategies in Calanus finmarchicus and Calanus glacialis in the northwestern part of the Barents Sea. In J.S. Gray \& M.E. Christiansen (eds.): Marine biology of polar regions and effects of stress on marine organisms. Pp. 141-155. New York: John Wiley and Sons.

ter Braak C.F.J. \& Smilauer P. 2002. CANOCO reference manual and CanoDraw for Windows user's guide: software for canonical community ordination. Version 4.5. Ithaca, NY:

Microcomputer Power.

Thor P., Nielsen T.G., Tiselius P., Juul-Pedersen T., Michel C., Møller E.F., Dahl K., Selander E. \& Gooding S. 2005. Post-spring bloom community structure of pelagic copepods in the Disko Bay, western Greenland. Journal of Plankton Research 27, 341-356.

Walkusz W. 2006. Temporal and spatial variability of zooplankton from two Svalbard fjords: Kongsfjorden and Hornsund. PhD thesis, Institute of Oceanology, Polish Academy of Sciences, Sopot, Poland.

Walkusz W., Kwasniewski S., Dmoch K., Hop H., Zmijewska M.I., Bielecka L., Falk-Petersen S. \& Sicinski J. 2004.
Characteristics of the Arctic and Antarctic mesozooplankton in the neritic zone during summer. Polish Polar Research 25, 275-291.

Walkusz W., Storemark K., Skau T., Gannefors C. \& Lundberg M. 2003. Zooplankton community structure; a comparison of fjords, open water and ice stations in the Svalbard area. Polish Polar Research 24, 149-165.

Weslawski J.M., Jankowski A., Kwasniewski S., Swerpel S. \& Ryg M. 1991. Summer hydrology and zooplankton in two Svalbard fiords. Polish Polar Research 12, 445-460.

Weslawski J.M., Kwasniewski S. \& Wiktor J. 1991. Winter in Svalbard fiord ecosystem. Arctic 44, 115-123.

Weslawski J.M., Pedersen G., Falk-Petersen S. \& Porazinski K. 2000. Entrapment of macroplankton in an Arctic fjord basin, Kongsfjorden, Svalbard. Oceanologia 42, 57-69.

Weslawski J.M., Zajaczkowski M., Kwasniewski S., Jezierski J. \& Moskal W. 1988. Seasonality in an Arctic fjord ecosystem: Hornsund, Spitsbergen. Polar Research 6, 185-189.

Wiborg K.F. 1955. Zooplankton in relation to hydrography in the Norwegian Sea. Report on Norwegian Fishery and Marine Investigations 11. Oslo: Fisheries Directorate.

Willis K.J., Cottier F.R. \& Kwasniewski S. 2007. Impact of warm water advection on the winter zooplankton community in an Arctic fjord. Polar Biology 31, 475-481.

Willis K.J., Cottier F., Kwasniewski S., Wold A. \& Falk-Petersen S. 2006. The influence of advection on zooplankton community composition in an Arctic fjord (Kongsfjorden, Svalbard). Journal of Marine Systems 61, 39-54.

Wlodarska-Kowalczuk M. \& Weslawski J.M. 2001. Impact of climate warming on Arctic benthic biodiversity: a case study of two Arctic glacial bays. Climate Research 18, 127-132.

Zajaczkowski M.J. \& Legezynska J. 2001. Estimation of zooplankton mortality caused by an Arctic glacier outflow. Oceanologia 43, 341-351. 